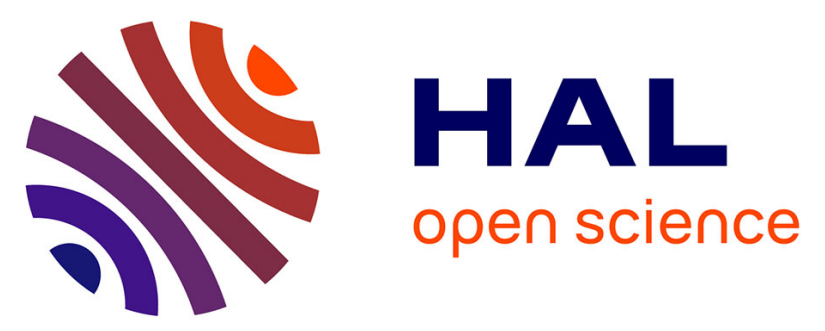

\title{
Spatial-temporal variations in phytoplankton size and colored detrital matter absorption at global and regional scales, as derived from twelve years of SeaWiFS data (1998-2009)
}

\author{
A. Bricaud, A. M. Ciotti, B. Gentili
}

\section{To cite this version:}

A. Bricaud, A. M. Ciotti, B. Gentili. Spatial-temporal variations in phytoplankton size and colored detrital matter absorption at global and regional scales, as derived from twelve years of SeaWiFS data (1998-2009). Global Biogeochemical Cycles, 2012, 26, 10.1029/2010GB003952 . hal-03502680

\author{
HAL Id: hal-03502680 \\ https://hal.science/hal-03502680
}

Submitted on 26 Dec 2021

HAL is a multi-disciplinary open access archive for the deposit and dissemination of scientific research documents, whether they are published or not. The documents may come from teaching and research institutions in France or abroad, or from public or private research centers.
L'archive ouverte pluridisciplinaire HAL, est destinée au dépôt et à la diffusion de documents scientifiques de niveau recherche, publiés ou non, émanant des établissements d'enseignement et de recherche français ou étrangers, des laboratoires publics ou privés. 


\title{
Spatial-temporal variations in phytoplankton size and colored detrital matter absorption at global and regional scales, as derived from twelve years of SeaWiFS data (1998-2009)
}

\begin{abstract}
A. Bricaud, ${ }^{1}$ A. M. Ciotti, ${ }^{2}$ and B. Gentili ${ }^{1}$
Received 31 August 2010; revised 24 June 2011; accepted 6 November 2011; published 25 January 2012.

[1] A procedure has been proposed by Ciotti and Bricaud (2006) to retrieve spectral absorption coefficients of phytoplankton and colored detrital matter (CDM) from satellite radiance measurements. This was also the first procedure to estimate a size factor for phytoplankton, based on the shape of the retrieved algal absorption spectrum, and the spectral slope of CDM absorption. Applying this method to the global ocean color data set acquired by SeaWiFS over twelve years (1998-2009), allowed for a comparison of the spatial variations of chlorophyll concentration ([Chl]), algal size factor $\left(\mathrm{S}_{\mathrm{f}}\right), \mathrm{CDM}$ absorption coefficient $\left(\mathrm{a}_{\mathrm{cdm}}\right)$ at $443 \mathrm{~nm}$, and spectral slope of CDM absorption $\left(\mathrm{S}_{\mathrm{cdm}}\right)$. As expected, correlations between the derived parameters were characterized by a large scatter at the global scale. We compared temporal variability of the spatially averaged parameters over the twelve-year period for three oceanic areas of biogeochemical importance: the Eastern Equatorial Pacific, the North Atlantic and the Mediterranean Sea. In all areas, both $S_{f}$ and $a_{c d m}(443)$ showed large seasonal and interannual variations, generally correlated to those of algal biomass. The CDM maxima appeared in some occasions to last longer than those of [Chl]. The spectral slope of CDM absorption showed very large seasonal cycles consistent with photobleaching, challenging the assumption of a constant slope commonly used in bio-optical models. In the Equatorial Pacific, the seasonal cycles of [Chl], $\mathrm{S}_{\mathrm{f}}, \mathrm{a}_{\mathrm{cdm}}(443)$ and $\mathrm{S}_{\mathrm{cdm}}$, as well as the relationships between these parameters, were strongly affected by the 1997-98 El Niño/La Niña event.
\end{abstract}

Citation: Bricaud, A., A. M. Ciotti, and B. Gentili (2012), Spatial-temporal variations in phytoplankton size and colored detrital matter absorption at global and regional scales, as derived from twelve years of SeaWiFS data (1998-2009), Global Biogeochem. Cycles, 26, GB1010, doi:10.1029/2010GB003952.

\section{Introduction}

[2] Recent studies dealing with ocean color data analysis have been dedicated to extract complementary information to chlorophyll $a$ concentration (hereafter noted [Chl]), the usual index describing algal biomass. These models or procedures are mainly split into two categories: (1) those retrieving optical properties related to phytoplankton, such as algal absorption coefficients or derived products, e.g., algal size or phytoplankton functional types (PFTs), or to the particulate pool, such as backscattering coefficients; (2) those retrieving information on Colored Dissolved Organic Matter (CDOM) or Colored Detrital Matter (CDM, which includes both CDOM and particulate detrital matter). The derivation of these new products from space, at both global and regional scales, can improve our understanding of the oceanic carbon cycle. Some biogeochemical processes can

\footnotetext{
${ }^{1}$ Laboratoire d'Océanographie de Villefranche, CNRS, Université Pierre et Marie Curie, Villefranche-sur-Mer, France.

${ }^{2}$ Laboratório Aquarela, Centro de Biologia Marinha, Universidade de São Paulo, São Sebastião, Brazil.
}

Copyright 2012 by the American Geophysical Union. 0886-6236/12/2010GB003952 be quantified in relation to algal size, or PFTs that categorize phytoplankton communities in terms of their size structure, composition and functioning. Most current biogeochemical models thus attempt to integrate information on PFTs [e.g., Aumont et al., 2003; Le Quéré et al., 2005], even though their benefit to predictive skills is still subject to discussion [Anderson, 2005]. Cell size, although not directly related to functional groups, has fundamental ecological implications [Sieburth et al., 1978] and provides important information for biogeochemical and food web modeling [see, e.g., Nair et al., 2008, and references therein]. Finally, CDM and CDOM play an essential role in the carbon cycle [e.g., Mopper and Kieber, 2002], and are also controlling the penetration of UV and blue radiation in the surface ocean layers, thus influencing phytoplankton and bacterial productivity.

[3] Retrieval of these new bio-optical products has been conducted using empirical or semi-analytical approaches, most of which have been evaluated and intercompared by a working group of the International Ocean Color Coordinating Group [Lee, 2006]. First, basic phytoplankton-related products such as algal light absorption coefficients were obtained, e.g. using the Quasi-Analytical Algorithm QAA [Lee et al., 2002], the Garver-Siegel-Maritorena (GSM) 
algorithm [Maritorena et al., 2002], or other approaches [see Lee, 2006]. Progressively, the proposed methods have focused toward more advanced products, such as the retrieval of phytoplankton groups [Gege, 1998; Alvain et al., 2005; Aiken et al., 2007; Raitsos et al., 2008], phytoplankton size classes [Uitz et al., 2006; Hirata et al., 2008] or phytoplankton dominant size [Ciotti and Bricaud, 2006; Devred et al., 2006; Mouw and Yoder, 2010]. Some other methods retrieve the particulate backscattering coefficient $\left(b_{b p}\right)$, which is then interpreted in terms of particle size distribution [Loisel et al., 2006; Brown et al., 2008] or phytoplankton size distribution [Kostadinov et al., 2009].

[4] Several methods have also been proposed to derive CDM or CDOM spectral absorption coefficients from satellite ocean color data. Some of these methods are based on empirical relationships between the magnitudes of absorption coefficients and remote sensing reflectances [Bélanger et al., 2008], reflectance ratios [Kahru and Mitchell, 2001; Johannessen et al., 2003; D'Sa and Miller, 2003; Mannino et al., 2008; Morel and Gentili, 2009], or reflectance "anomalies" [Brown et al., 2008]. All the above mentioned methods (except the two latter ones) were developed and tested for the coastal ocean, and most of them retrieve the absorption coefficients of CDOM (the main component of CDM). On the other hand, methods based on semi-analytical bio-optical models are designed for retrieving simultaneously [Chl] and CDM absorption coefficients at one or several wavelengths, along with other parameters such as the particulate backscattering coefficient [Carder et al., 1999; Lee et al., 2002; Maritorena et al., 2002]. These bio-optical models generally combine CDOM and detrital particles into a single component, because of their hardly distinguishable spectral signatures. At the global scale, the most widely used method is that of Maritorena et al. [2002], based on the GSM model, which has proved to retrieve the CDM absorption coefficient with some scatter, but without significant bias [Siegel et al., 2002]. Possibly, some of the scatter originates from the assumption made in the GSM algorithm that the spectral slope of CDM absorption is constant. There is some evidence that this slope is variable spatially and seasonally, both in the coastal ocean [Blough and Del Vecchio, 2002; Babin et al., 2003; Mannino et al., 2008], and in the open ocean, where the spectral behavior of CDM is driven mainly by photooxidation [Coble, 2007].

[5] In the method we proposed earlier [Ciotti and Bricaud, 2006, hereinafter CB2006], the total non-water light absorption coefficients, as derived from satellite radiances, are partitioned into the absorption coefficients of CDM and phytoplankton. CB2006 also retrieves two additional parameters: a size factor for phytoplankton $\left(\mathrm{S}_{\mathrm{f}}\right)$, based on the shape of the retrieved algal absorption spectrum, and the spectral slope for CDM absorption. It is emphasized that, whereas several methods are now available to retrieve information on phytoplankton size and CDM content, the CB2006 procedure is, to our knowledge, the only method retrieving the spectral slope of CDM absorption.

[6] Retrievals were compared to in situ data for continental shelf waters off Brazil, where simultaneous satellite and in situ data were available [Ciotti and Bricaud, 2006]. The comparison was later expanded to a more diversified data set [Lee, 2006], and CB2006 performances for retrieving the magnitudes of spectral absorption coefficients were found to be similar to those of other current approaches [Bricaud et al., 2006]. After some improvements, CB2006 was included in an extensive intercomparison exercise evaluating various procedures against a data set of 6504 in situ observations in the global ocean [Brewin et al., 2011]. The CB2006 method was found to detect correctly the picoplankton and microplankton dominance for $77 \%$ and $84 \%$, respectively, of the global data set. Proper validation of bio-optical models remains complex and challenging, due among other reasons to spatial and temporal differences between ground truth and satellite-derived data.

[7] The aim of this paper is to apply the CB2006 method to the currently available time series of SeaWiFS observations, in order to study the spatial-temporal variations of absorption by phytoplankton, absorption by CDM (as an index of the CDM content of waters), the phytoplankton size factor $\mathrm{S}_{\mathrm{f}}$, and the spectral slope of CDM absorption over this period. As the procedure allows for global scale views, we will focus our discussion on meridional and seasonal trends, but provide also analyses for three selected oceanic areas. All studied areas are of remarkable biogeochemical importance, and present distinct temporal patterns regarding both algal size and CDM content in the literature. The observed seasonal and interannual trends are compared with those of [Chl], so as to evaluate the potential additional information provided by these products.

\section{Data and Methods}

\subsection{Reminder of the Original Procedure}

[8] The original procedure, described in detail by Ciotti and Bricaud [2006], comprises three successive steps: (1) remote sensing reflectances at the 5 SeaWiFS wavelengths $(412,443,490,510$ and $555 \mathrm{~nm})$ are converted into total absorption coefficients using the method proposed by Loisel and Stramski [2000]; (2) for all 5 wavelengths, the total absorption coefficients minus the contribution of pure seawater [Pope and Fry, 1997], are partitioned into the contributions of phytoplankton and CDM, providing both the magnitude of absorption coefficients of phytoplankton and CDM and their spectral dependences. Two methods were tested: an analytical decomposition (M1) and a nonlinear optimization technique that minimizes the differences between the observed and computed values of total nonwater absorption coefficients (M2). For both methods, the use of the 555-nm band was found to induce a decrease in performances and was discarded. In the present study, only M2 was used for deriving all coefficients; (3) the algal absorption spectrum $\left(\mathrm{a}_{\text {phy }}\right)$ is normalized at the wavelength $505 \mathrm{~nm}$, and the (dimensionless) size factor $\mathrm{S}_{\mathrm{f}}$ is derived from the shape of the spectrum, using the spectral mixing model proposed by Ciotti et al. [2002]. This model states that any (normalized) absorption spectrum is a linear combination of two spectra corresponding to pure picophytoplankton $\left(S_{\mathrm{f}}=1\right)$ and pure microphytoplankton $\left(\mathrm{S}_{\mathrm{f}}=0\right)$. Therefore, $\mathrm{S}_{\mathrm{f}}$ (varying between 0 and 1 ) can be considered as specifying the relative contribution of picophytoplankton to absorption (note that the picophytoplankton vector used in CB2006 has been modified with respect to that defined by Ciotti et al. [2002]). It is emphasized that with this procedure, $\mathrm{S}_{\mathrm{f}}$ is only linked to the shape of the normalized algal 
absorption spectrum, and therefore is allowed to vary independently from [Chl].

\subsection{Revised Procedure}

[9] CB2006 was first applied to SeaWiFS data at the global scale using the method of Loisel and Stramski as revised by Loisel and Poteau [2006] (which included a modified parameterization of the diffuse attenuation coefficient $\mathrm{K}_{\mathrm{d}}(\lambda)$ ). Even with this revised method, the retrieved non-water absorption coefficients were systematically lower than 0 in the clearest waters of the world ocean (Pacific and Atlantic subtropical gyres), resulting from a negative bias in the retrieval of total absorption coefficients. This led to a new revision of the Loisel and Stramski method (H. Loisel et al., manuscript in preparation), in which the $\mathrm{h}$ function [see Loisel and Stramski, 2000, equation 8 and Figure 2] is now parameterized as a function of the sun zenith angle and $\mathrm{K}_{\mathrm{d}}(\lambda)$ for each wavelength.

[10] This new revision provided positive absorption coefficients over most clear waters, and was thus introduced in CB2006. Regardless this improvement, it must be noted that in clear waters ([Chl] $<0.1 \mathrm{mg} \mathrm{m}^{-3}$ ), about $90 \%$ of the total absorption coefficient at $510 \mathrm{~nm}$, as measured in the field, originates from water molecules. In such waters, the retrieval of non-water absorption coefficients is therefore very challenging and must be considered only as indicative.

[11] In the next step of the procedure (nonlinear optimization), some improvements were also introduced. $\mathrm{S}_{\mathrm{f}}$, $a_{c d m}(443)$ and $S_{c d m}$ were set to initial values and then adjusted through an iterative routine (quasi-Newton method), by using a bound constrained optimization [Byrd et al., 1995] in which $\mathrm{S}_{\mathrm{f}}, \mathrm{a}_{\mathrm{cdm}}(443)$ and $\mathrm{S}_{\mathrm{cdm}}$ were forced to vary in the ranges $[-0.5-1.5],\left[0-10 \mathrm{~m}^{-1}\right]$ and $\left[0-0.05 \mathrm{~nm}^{-1}\right]$, respectively. Convergence was assumed when the minimum of the function [see CB2006, equation 11] was $<0.05$, and when no convergence was reached the pixel was flagged. The occurrence of multiple solutions was detected by comparing the results using different initial values of each parameter. For a small number of pixels, multiple solutions occurred (i.e., solutions were dependent on the initial values), and these pixels were also flagged.

\subsection{Satellite Data}

[12] CB2006 was applied to the SeaWiFS L3 (monthly and 8-day means) global mapped GAC data (processing version 2009.1) over a twelve-year period (January 1998December 2009), with a spatial resolution of $9.2 \mathrm{~km}$ at the Equator. Remote sensing reflectances at four wavelengths $(412,443,490,510 \mathrm{~nm})$ and chlorophyll concentration maps (provided by the OC4v5 algorithm) were downloaded from the NASA Goddard Space Flight Center Distributed Active Archive Center (DAAC) website (http://oceandata.sci.gsfc. nasa.gov/).

[13] Over given oceanic areas, we computed arithmetic means, as recommended for biogeochemical applications [see Campbell et al., 1995; Bricaud et al., 2002], to form the time series. Depending on both season and latitude, the 8day images can be largely affected by cloud cover (or there can be no data acquisition), thus biasing the values of spatial means. Therefore our time series, for a given area, contains only means for which the number of valid pixels for a given 8-day period was superior to $30 \%$ of the average number of pixels (median) for the whole time series.

\section{Results and Discussion}

\subsection{Spatial Trends at the Global Scale}

[14] The spatial variations of chlorophyll $a$ concentration ([Chl]), algal size factor $\left(\mathrm{S}_{\mathrm{f}}\right)$, absorption coefficient of CDM at $443 \mathrm{~nm}\left(\mathrm{a}_{\mathrm{cdm}}(443)\right)$, and spectral slope of CDM absorption $\left(\mathrm{S}_{\mathrm{cdm}}\right)$, are displayed in Figures 1a-1d, for four months representative of the four seasons, and for the year 2007 taken as an example. Results of regression analyses between the various products are given in Table 1 .

\subsubsection{Phytoplankton Size Factor, Algal Absorption} and Chlorophyll $a$ Concentration

[15] For each season, a clear inverse correlation between $\mathrm{S}_{\mathrm{f}}$ and [Chl] was observed (Figures 1a-1d, top; note log scales for [Chl]), consistent with the general observation that large and pigment packaged cells $\left(\mathrm{S}_{\mathrm{f}}\right.$ close to 0$)$ tend to dominate (both in biomass and optically) in eutrophic, chlorophyll-rich waters, while picophytoplankton and pigment unpackaged cells ( $S_{\mathrm{f}}$ close to 1$)$ are usually dominant in clear waters (after the hypothesis of Yentsch and Phinney [1989]). The robustness of the relationships between $\mathrm{S}_{\mathrm{f}}$ and [Chl], at the global scale, and for each season, can be observed in the scatterplots (Figure 2). $\mathrm{S}_{\mathrm{f}}$ exhibits a global decreasing trend with increasing [Chl], with a large scatter (e.g., for $[\mathrm{Chl}]=0.3 \mathrm{mg} \mathrm{m}^{-3}, \mathrm{~S}_{\mathrm{f}}$ varies between 0.4 and 0.8 ). Regression analyses for the different latitude ranges showed no particular trend. In addition, the average relationships between $\mathrm{S}_{\mathrm{f}}$ and [Chl] are similar for the four seasons (Figure 2, bottom). Although the noise around the average relationships partly results from uncertainties in the $\mathrm{S}_{\mathrm{f}}$ retrieval, it may also contain actual information. For instance, it is consistent with the fact that, for a given [Chl], the dominant size of populations (as retrieved from HPLC pigment measurements) can be highly variable from one oceanic area to the other [e.g. Bricaud et al., 2004].

[16] Note that $\mathrm{S}_{\mathrm{f}}$ is higher than 1 for numerous pixels in the clearest waters, indicating that the phytoplankton absorption spectra derived here are "sharper" than that assumed to represent "pure picophytoplankton." We checked that this does not occur when $\mathrm{S}_{\mathrm{f}}$ is retrieved from absorption spectra measured at sea, which suggests that the absorption spectrum representing pure picoplankton is correct. Therefore, the $\mathrm{S}_{\mathrm{f}}$ overestimate in very clear waters is likely due to the combined errors in atmospheric corrections applied to SeaWiFS measurements and in the inversion of remote sensing reflectances at the sea level. It is important to recall that the $\mathrm{S}_{\mathrm{f}}$ (and all other parameters) retrievals for the clearest waters are very uncertain because total absorption coefficients are close to those of pure seawater.

[17] The CB2006 procedure also retrieves absorption coefficients of phytoplankton $\left(a_{\text {phy }}\right)$ at all wavelengths: the $a_{\text {phy }}$ spectrum, normalized at $505 \mathrm{~nm}$, is straightforwardly derived from the $S_{f}$ value (which rules the shape of the spectrum), and then the $a_{\text {phy }}$ spectrum is scaled using the $a_{\text {phy }}(505)$ value, empirically related to [Chl] [CB2006, equations 9 and 10]. The $\mathrm{a}_{\text {phy }}(443)$ coefficients covary with [Chl] for the four seasons (Figure 3), and no seasonal trends appear. These relationships can be compared with that derived from in situ measurements, performed at different 
a)
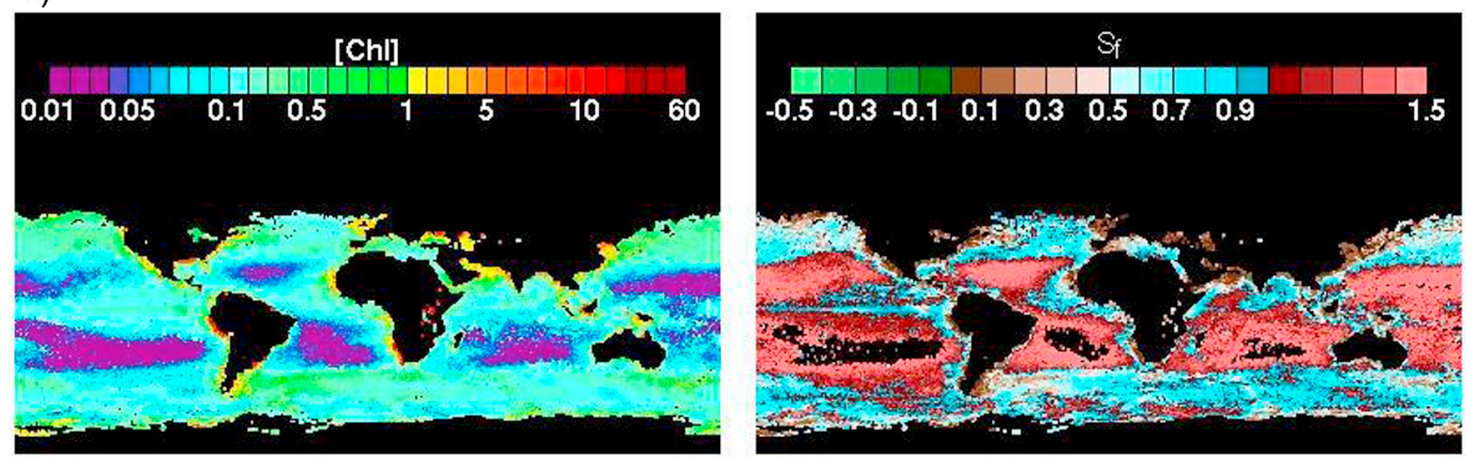

February 2007
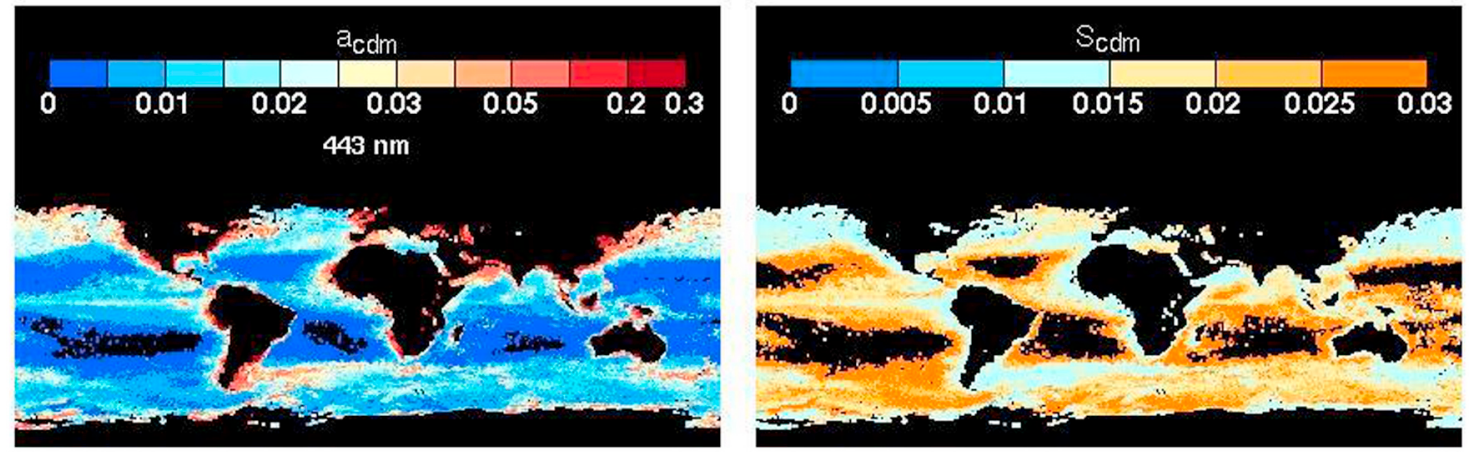

b)
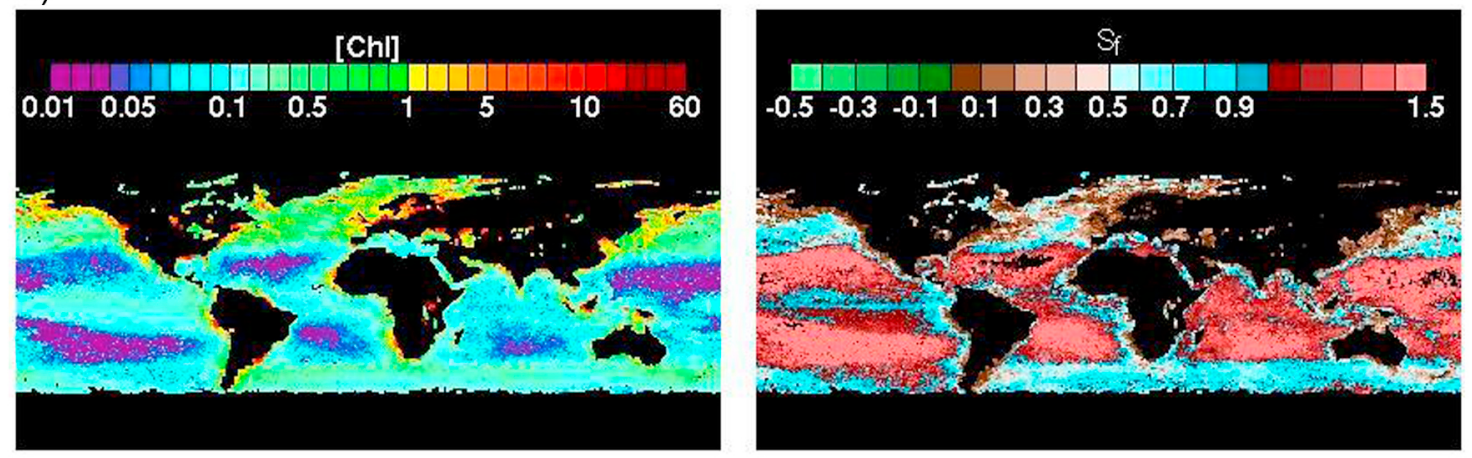

May 2007
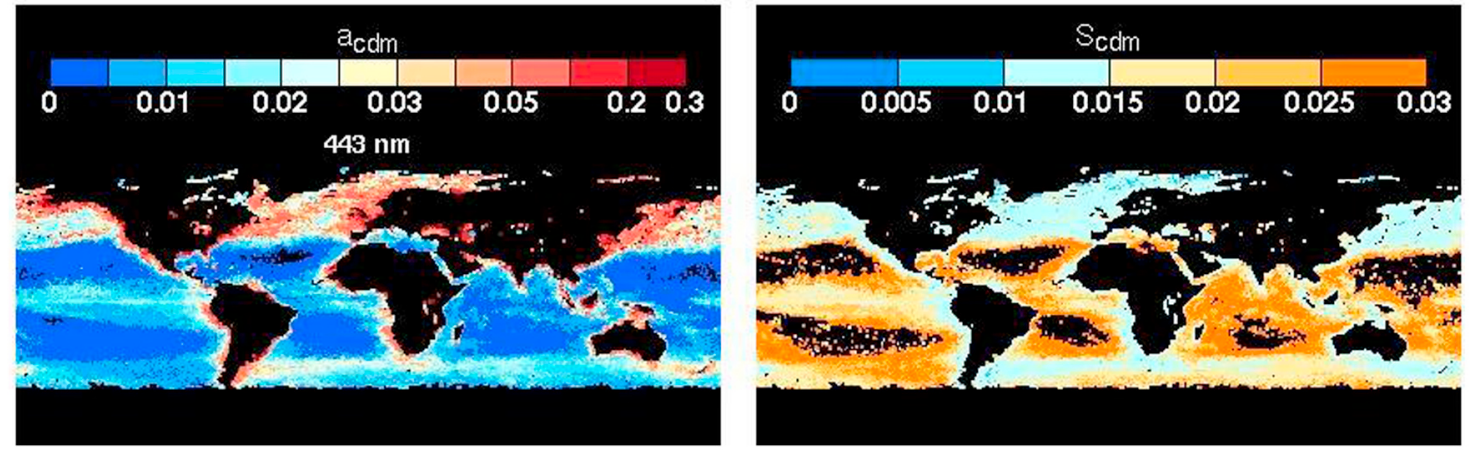

Figure 1. Monthly maps derived from the SeaWiFS monthly composite of reflectance for (a) February 2007, (b) May 2007, (c) August 2007, and (d) November 2007: (top to bottom and left to right) chlorophyll $a$ concentration (in $\mathrm{mg} \mathrm{m}^{-1}$ ), size factor of phytoplankton $\mathrm{S}_{\mathrm{f}}$ (dimensionless), absorption coefficient of colored detrital matter (CDM) at $443 \mathrm{~nm}\left(\right.$ in $\left.^{-1}\right)$, and spectral slope of CDM absorption $\left(\mathrm{S}_{\mathrm{cdm}}\right.$, in $\mathrm{nm}^{-1}$ ). Color scales are given for each parameter and are common to Figures 1a-1d. Scales are logarithmic for [Chl] and $\mathrm{a}_{\mathrm{cdm}}(443)$, and linear for $\mathrm{S}_{\mathrm{f}}$ and $\mathrm{S}_{\mathrm{cdm}}$. 
c)
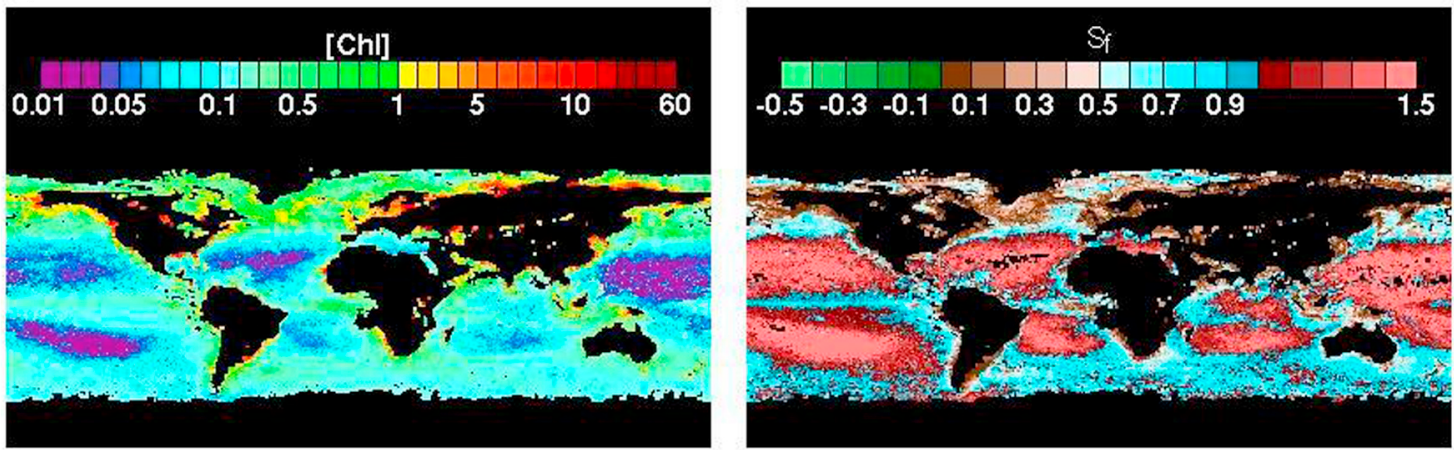

\section{August 2007}
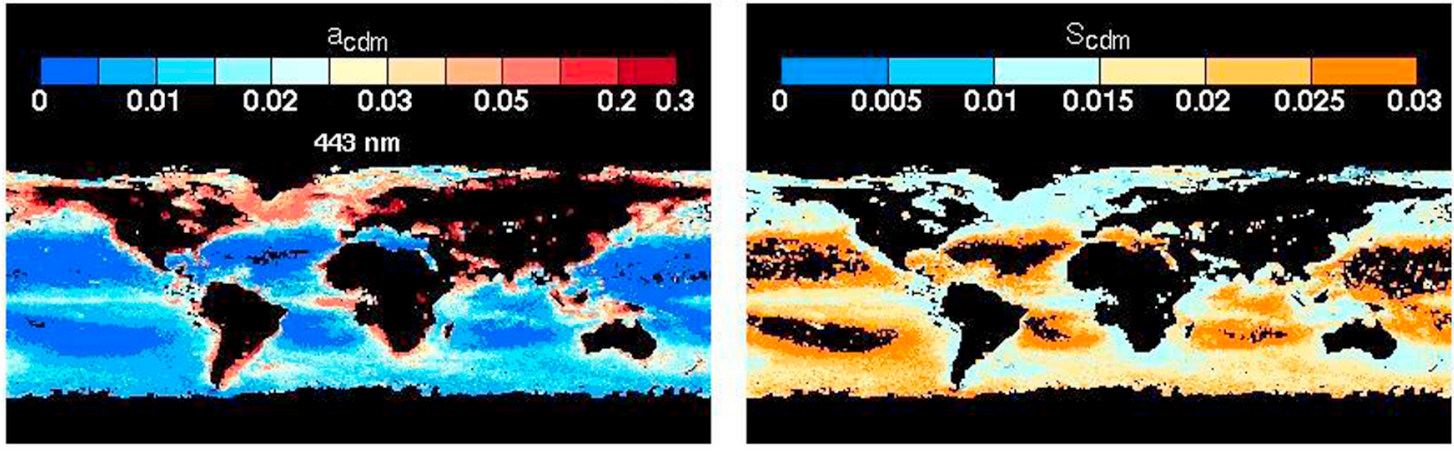

d)
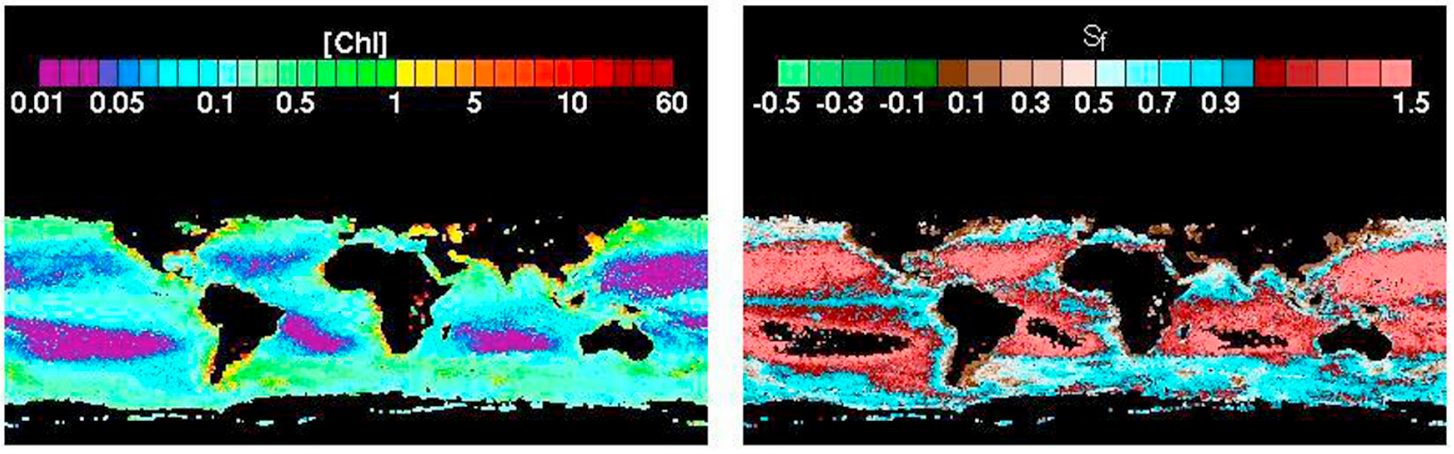

November 2007
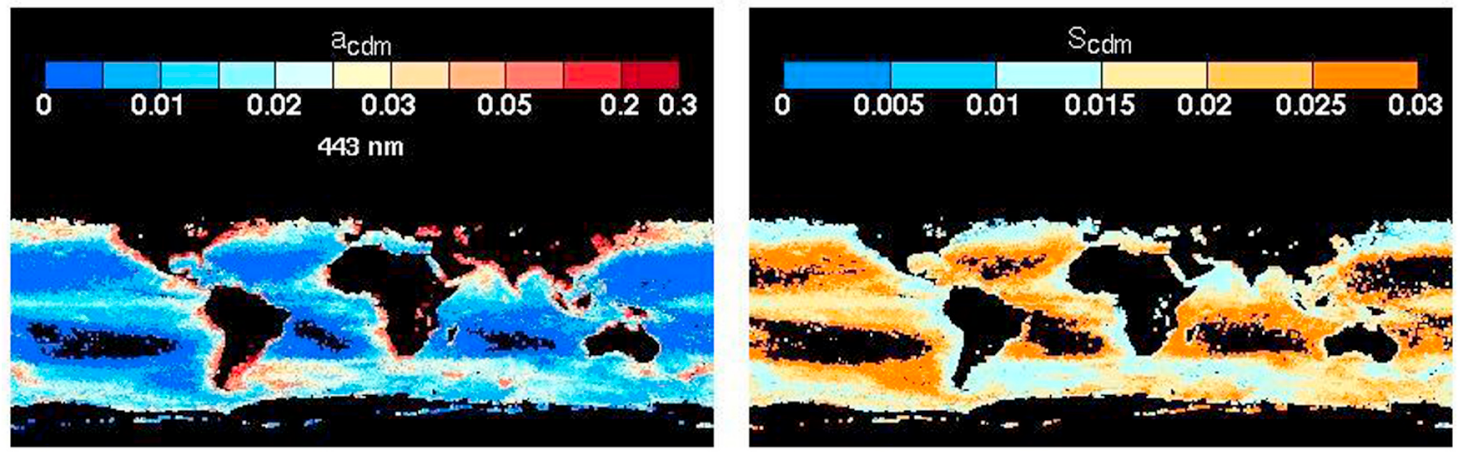

Figure 1. (continued) 
Table 1. Average Relationships Linking the Spatial Variations of Chlorophyll $a$ Concentration ([Chl]), the Size Factor of Phytoplankton $\left(\mathrm{S}_{\mathrm{f}}\right)$, the Absorption Coefficient of CDM at $443 \mathrm{~nm}\left(\mathrm{a}_{\mathrm{cdm}}(443)\right)$, and the Spectral Slope of CDM Absorption ( $\left.\mathrm{S}_{\mathrm{cdm}}\right)$, for the Four Monthly Maps Shown in Figure $1^{\mathrm{a}}$

\begin{tabular}{|c|c|c|c|c|}
\hline & Slope & Intercept & Determination Coefficient & Residual Standard Error \\
\hline \multicolumn{5}{|c|}{$S_{f}$ versus log [Chl] } \\
\hline Feb. 2007 & -0.961 & 0.198 & 0.940 & 0.079 \\
\hline May 2007 & -0.936 & 0.211 & 0.936 & 0.090 \\
\hline Aug. 2007 & -0.949 & 0.200 & 0.923 & 0.096 \\
\hline Nov. 2007 & -0.934 & 0.231 & 0.946 & 0.075 \\
\hline \multicolumn{5}{|c|}{$\log \left(a_{p h y}(443)\right)$ versus $\log [\mathrm{Chl}]$} \\
\hline Feb. 2007 & 0.458 & -1.468 & 0.982 & 0.020 \\
\hline May 2007 & 0.462 & -1.469 & 0.981 & 0.024 \\
\hline Aug. 2007 & 0.456 & -1.473 & 0.976 & 0.025 \\
\hline Nov. 2007 & 0.470 & -1.457 & 0.983 & 0.020 \\
\hline Bricaud et al. [1998] & 0.620 & -1.426 & & \\
\hline \multicolumn{5}{|c|}{$\log \left(a_{c d m}(443)\right)$ versus $\log [C h l]$} \\
\hline Feb. 2007 & 1.095 & -1.153 & 0.927 & 0.100 \\
\hline May 2007 & 1.067 & -1.169 & 0.936 & 0.103 \\
\hline Aug. 2007 & 1.109 & -1.128 & 0.933 & 0.103 \\
\hline Nov. 2007 & 1.070 & -1.161 & 0.932 & 0.097 \\
\hline \multicolumn{5}{|c|}{$\log S_{c d m}$ versus $\log \left(a_{c d m}(443)\right)$} \\
\hline Feb. 2007 & -0.448 & -2.574 & 0.938 & 0.042 \\
\hline May 2007 & -0.426 & -2.534 & 0.928 & 0.048 \\
\hline Aug. 2007 & -0.419 & -2.519 & 0.906 & 0.054 \\
\hline Nov. 2007 & -0.448 & -2.581 & 0.940 & 0.042 \\
\hline
\end{tabular}

${ }^{a}$ The corresponding regression lines (lin-log for $\mathrm{S}_{\mathrm{f}}, \log -\log$ for $\mathrm{a}_{\text {phy }}(443)$, $\mathrm{a}_{\mathrm{cdm}}(443)$ and $\mathrm{S}_{\mathrm{cdm}}$ ) are displayed in Figures 2-5.

seasons [Bricaud et al., 1998]. Note that CB2006 constrains only $\mathrm{a}_{\text {phy }}(505)$ to vary with [Chl] according to Bricaud et al. [1998], while the spectral shape of $a_{\text {phy }}$ is determined independently. The $\mathrm{a}_{\text {phy }}(443)$ coefficients derived from satellite measurements are in agreement with those measured in the field in the [Chl] range $0.3-1 \mathrm{mg} \mathrm{m}^{-3}$ (Figure 3, bottom). This consistency suggests that the shapes of phytoplankton absorption spectra, as derived from satellite measurements, are globally consistent with in situ observations in this [Chl] range. In clear waters, the retrieved $a_{\text {phy }}(443)$ coefficients are, on average, higher than the measured coefficients (by $58 \%$ when $[\mathrm{Chl}]=0.03 \mathrm{mg} \mathrm{m}^{-3}$ ), while they are lower for high [Chl] values (by $37 \%$ when $[\mathrm{Chl}]=10 \mathrm{mg} \mathrm{m}^{-3}$ ). These divergences indicate that for low and high [Chl] values, absorption spectra derived from satellite measurements differ in shape from those generally observed in the field.

\subsubsection{CDM Absorption and Chlorophyll $a$} Concentration

[18] The spatial variations of CDM absorption at $443 \mathrm{~nm}$ (Figures 1a-1d, bottom) display large-scale patterns, such as the asymmetry between the North and the South Pacific, and the overall increase in CDM toward higher latitudes in both North Atlantic and North Pacific oceans. Assuming that CDOM is, in most oceanic situations, the dominant component of CDM [Siegel et al., 2002], the retrieved patterns are consistent with recent in situ measurements taken along large transects [Nelson et al., 2007; Swan et al., 2009]. At the global scale and at all seasons, the spatial variations in $a_{\text {cdm }}(443)$ appear to be correlated to those in [Chl] (Figures $1 \mathrm{a}-1 \mathrm{~d}$ and 4), with no seasonal variability (Figure 4, bottom). Such general covariation is expected, as in oceanic waters, away from terrigenous influences, CDOM is essentially a product of phytoplankton decay [Kopelevich and Burenkov, 1977]. Also, inputs of CDOM and nutrients from deep waters can occur in some areas, through vertical mixing or upwelling, so that high values of CDOM and algal biomass may occur either simultaneously or with temporal lags [e.g., Siegel et al., 2002]. The large scatter observed around the $\mathrm{a}_{\mathrm{cdm}}(443)$ versus [Chl] relationships, actually, is consistent with the temporal decoupling between CDOM and algal biomass, as CDOM tends to be a long-lived product of phytoplankton degradation, reflecting the biological history of a given oceanic water mass rather than its present biomass content [Kopelevich and Burenkov, 1977]. This has been confirmed by a number of studies in the past fifteen years that discuss CDOM spatial distribution as a function of various processes within the microbial and planktonic foodweb [see, e.g., Kitidis et al., 2006, and references therein]. In addition, at the surface of the ocean, spatial patterns of CDOM are also controlled by the incident light level that drives photo-oxidation processes [e.g., Chen and Bada, 1992]. Thus, at large scale, CDOM spatial distribution results from the combined effects of the meridional overturning circulation and biogeochemical processes such as phytoplankton degradation, microbial production and photobleaching [Nelson et al., 2010].

[19] The central trend of $\mathrm{a}_{\mathrm{cdm}}(443)$ versus [Chl] relationships (Figure 4, bottom) can be compared to the global relationship derived by A. Morel (personal communication, 2010) for CDOM only,

$$
\mathrm{a}_{\mathrm{cdom}}(443)=0.07315[\mathrm{Chl}]^{0.858}
$$

The above relationship was derived from CDOM estimates at the global scale from SeaWiFS reflectances for the year 2007, using the method of Morel and Gentili [2009]. Considering that these approaches are totally independent from 

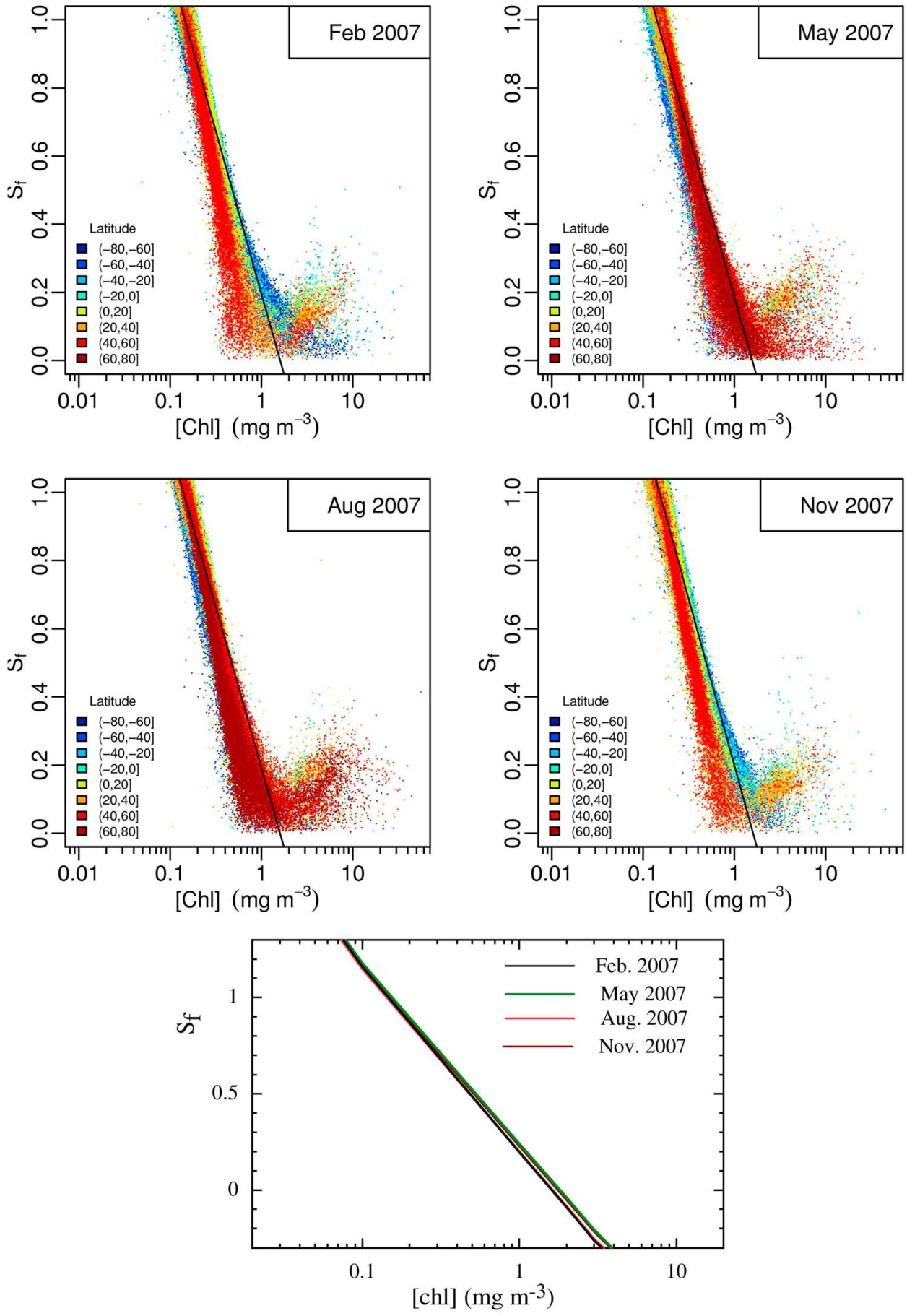

Figure 2. Variations of the size factor of phytoplankton ( $\mathrm{S}_{\mathrm{f}}$, dimensionless) as a function of chlorophyll $a$ concentration, [Chl] (in $\mathrm{mg} \mathrm{m}^{-3}$ ), corresponding to the monthly maps displayed in Figure 1. Colors correspond to latitude bands as indicated in inset. The lin-log regression lines correspond to the best fit for the pixels within the $[\mathrm{Chl}]$ range $0.1-10 \mathrm{mg} \mathrm{m}^{-3}$. The four average relationships are compared in the lower panel. The corresponding equations are given in Table 1.

each other, the consistency observed (except in the clearest waters) between the average relationships is encouraging.

\subsubsection{Spectral Slope and Amplitude of CDM}

\section{Absorption}

[20] The spatial variations of the slope of CDM absorption, $\mathrm{S}_{\mathrm{cdm}}$, retrieved by CB2006 appear to be inversely correlated to those of $a_{c d m}(443)$ (Figures $1 \mathrm{a}-1 \mathrm{~d}$, bottom).
Scatterplots corresponding to each season (Figure 5) suggest that the overall range of $\mathrm{S}_{\mathrm{cdm}}$ could be rather large (approximately 0.010 to $0.050 \mathrm{~nm}^{-1}$ ), and reveal the same decreasing trend with increasing $\mathrm{a}_{\mathrm{cdm}}$ values, with no seasonal variability (Figure 5, bottom). As for $\mathrm{S}_{\mathrm{f}}$, the large $\mathrm{S}_{\mathrm{cdm}}$ values $\left(>0.03 \mathrm{~nm}^{-1}\right)$ obtained in very clear waters must be 

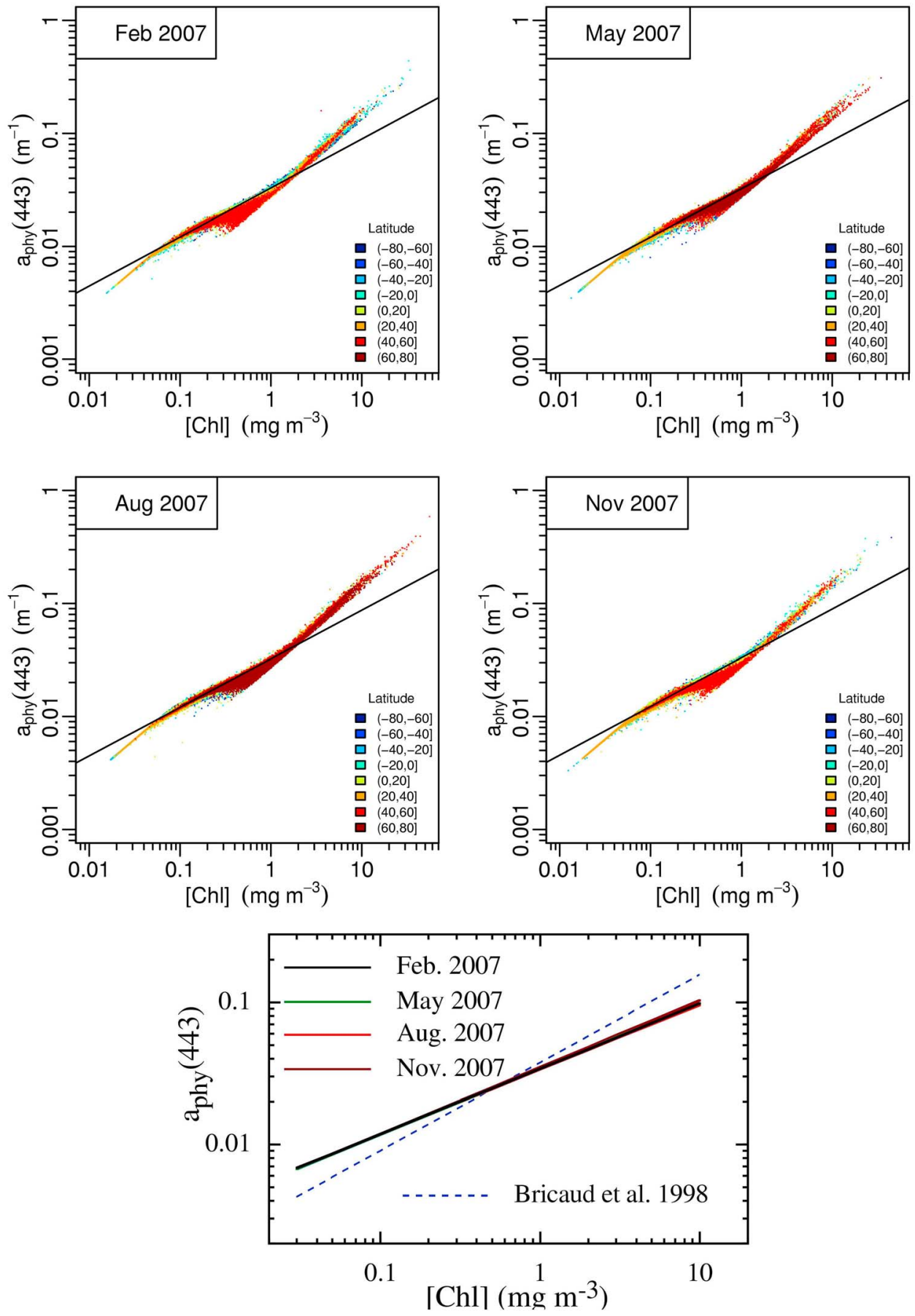

Figure 3. Same as Figure 2, for the absorption coefficient of phytoplankton at $443 \mathrm{~nm}, \mathrm{a}_{\text {phy }}(443)$ (in $\mathrm{m}^{-1}$ ). This figure shows log-log regression lines (best fits for the [Chl] range $0.1-10 \mathrm{mg} \mathrm{m}^{-3}$ ).

considered with caution, because they are derived from extremely weak non-water absorption coefficients.

[21] As in the global ocean CDM is largely dominated by CDOM [Siegel et al., 2002], the observed trends can be compared to those previously observed for CDOM. The inverse relationship between $\mathrm{S}_{\mathrm{cdm}}$ and $\mathrm{a}_{\mathrm{cdm}}(443)$ is consistent with many previous observations based on in situ measurements of CDOM absorption [e.g., Carder et al., 1989; Nelson and Siegel, 2002; Twardowski et al., 2004; Bricaud et al.,
2010]. The variations in $S_{\text {cdom }}$ are generally considered to reflect variations in the composition of the CDOM pool, such as the relative proportions of humic and fulvic acids [Carder et al., 1989], of semi-labile and refractory fractions [Nelson and Siegel, 2002], and the photo-degradation of some CDOM components [Green and Blough, 1994; Whitehead et al., 2000]. To a lesser extent, the variable contribution of non-algal absorption to the CDM may also contribute to the overall variability in $\mathrm{S}_{\mathrm{cdm}}$. 

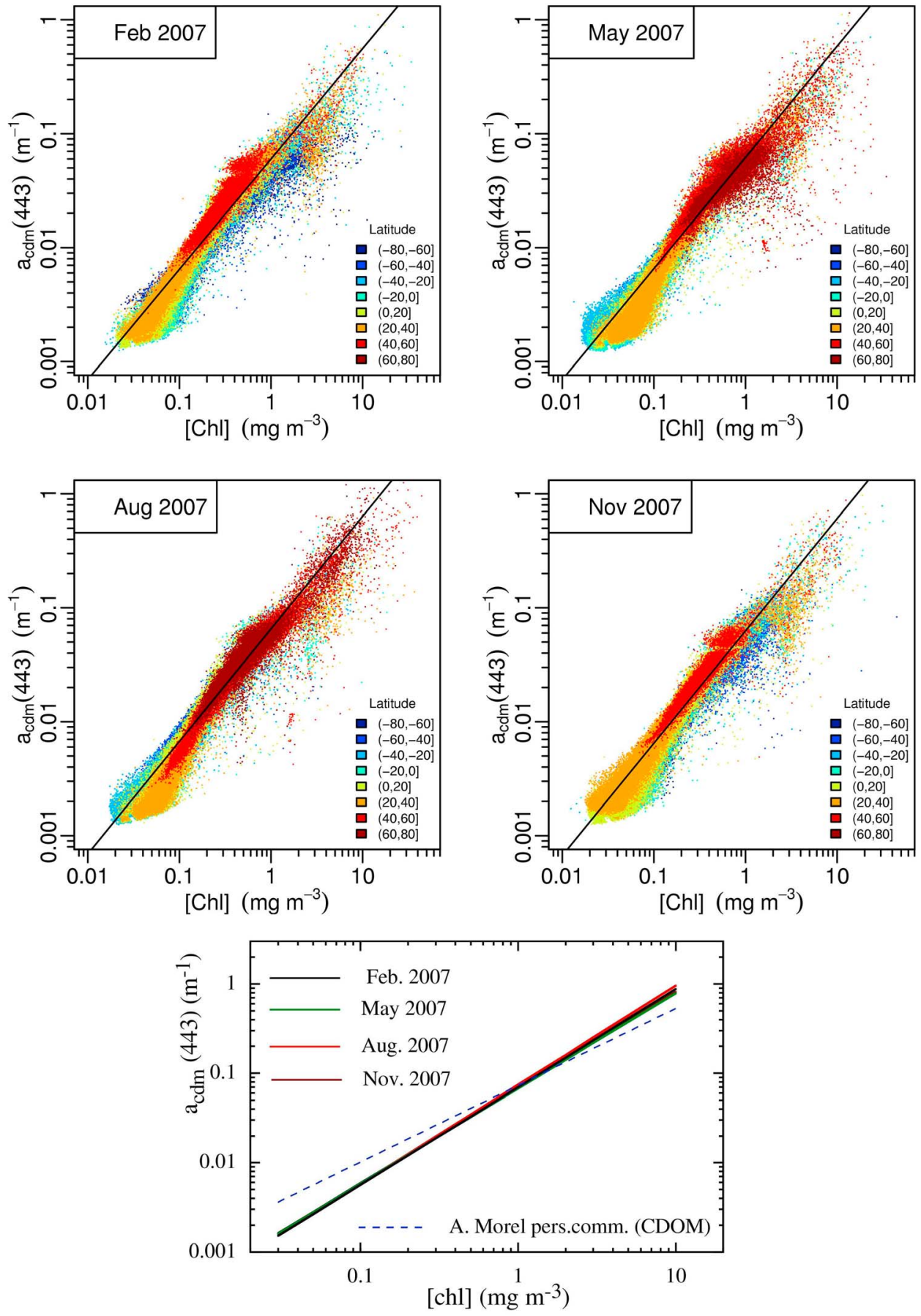

Figure 4. Same as Figure 2, for the absorption coefficient of CDM at $443 \mathrm{~nm}, \mathrm{a}_{\mathrm{cdm}}(443)$ (in $\mathrm{m}^{-1}$ ). This figure shows log-log regression lines (best fits for the [Chl] range $0.1-10 \mathrm{mg} \mathrm{m}^{-3}$ ).

\subsection{Temporal Trends at Regional Scales}

[22] The temporal evolutions of algal biomass (and other parameters related to phytoplankton) and CDM are highly variable with geographical region, and so, at the global scale are blurry representations of multiple patterns. Therefore, to discuss seasonal and interannual variations of the various retrieved parameters by the modified CB2006 method, we focused our analysis on three contrasted oceanic regions, recognized as biogeochemically important: the Eastern Equatorial Pacific, the North Atlantic and the Mediterranean
Sea (Figures 6, 7, and 8, respectively). The first two regions have been recently analyzed in terms of PFT occurrence, using the PHYSAT method [Alvain et al., 2008], which provides an opportunity for a comparison of results. For this reason, their geographical delimitations (indicated in the following sections) follow those chosen by Alvain et al. [2008].

3.2.1. Eastern Equatorial Pacific $\left(5^{\circ} \mathrm{S}-5^{\circ} \mathrm{N}, 8^{\circ} \mathrm{W}-170^{\circ} \mathrm{W}\right)$

[23] This oceanic region is characterized as one of the High Nutrient-Low Chlorophyll (HNLC) areas, because in 

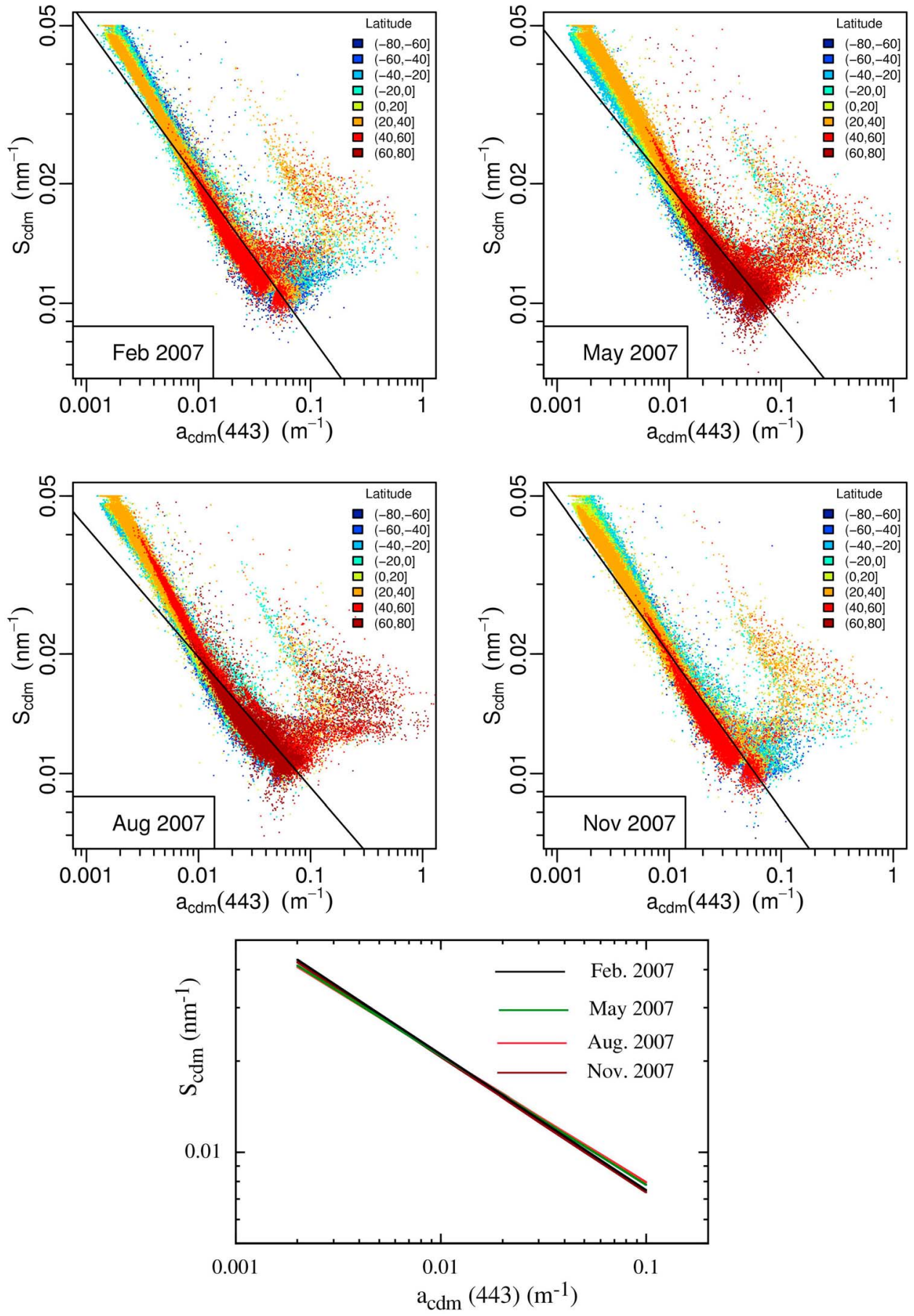

Figure 5. Variations of the spectral slope of CDM absorption $\left(\mathrm{S}_{\mathrm{cdm}}, \mathrm{in}^{-1}\right)$ as a function of the absorption coefficient of CDM at $443 \mathrm{~nm}$ (in $\mathrm{m}^{-1}$ ), corresponding to the monthly maps displayed in Figure 1 . The log-log regression lines correspond (as in Figures 2-4) to the best fit for the pixels within the [Chl] range $0.1-10 \mathrm{mg} \mathrm{m}^{-3}$ (corresponding approximately to the range $0.008-1 \mathrm{~m}^{-1}$ for $\mathrm{a}_{\mathrm{cdm}}(443)$ ).

spite of nutrient fertilization by steady upwelling to the surface layers, the average [Chl] values remain low, as a result of iron limitation and intense grazing [Landry et al., 1997]. The seasonal and interannual variations of spatially averaged [Chl] are rather weak (Figure 6, left), with the remarkable exception of the year 1998 which corresponds to the mature phase of an El Niño event (January to April) followed by a La Niña period (May to September).
[24] In situ observations have revealed that this area is dominated by phytoplankton smaller than $5 \mu \mathrm{m}$ [Chavez et al., 1990], and Alvain et al. [2008], using the PHYSAT method, have found that Synechococcus was dominant yearround. Excluding the January-September 1998 period, the retrieved $S_{f}$ values (averaged over the entire region) oscillate between 0.9 and more than 1, thus suggesting the dominance 

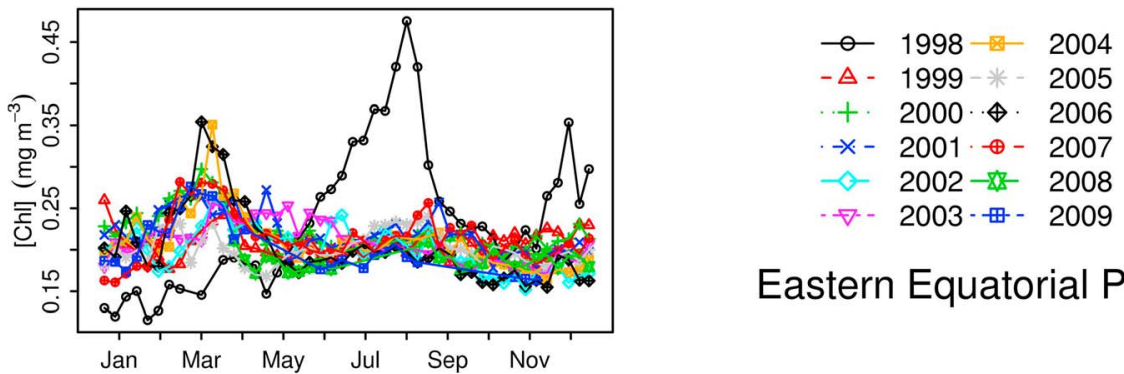

\section{Eastern Equatorial Pacific}
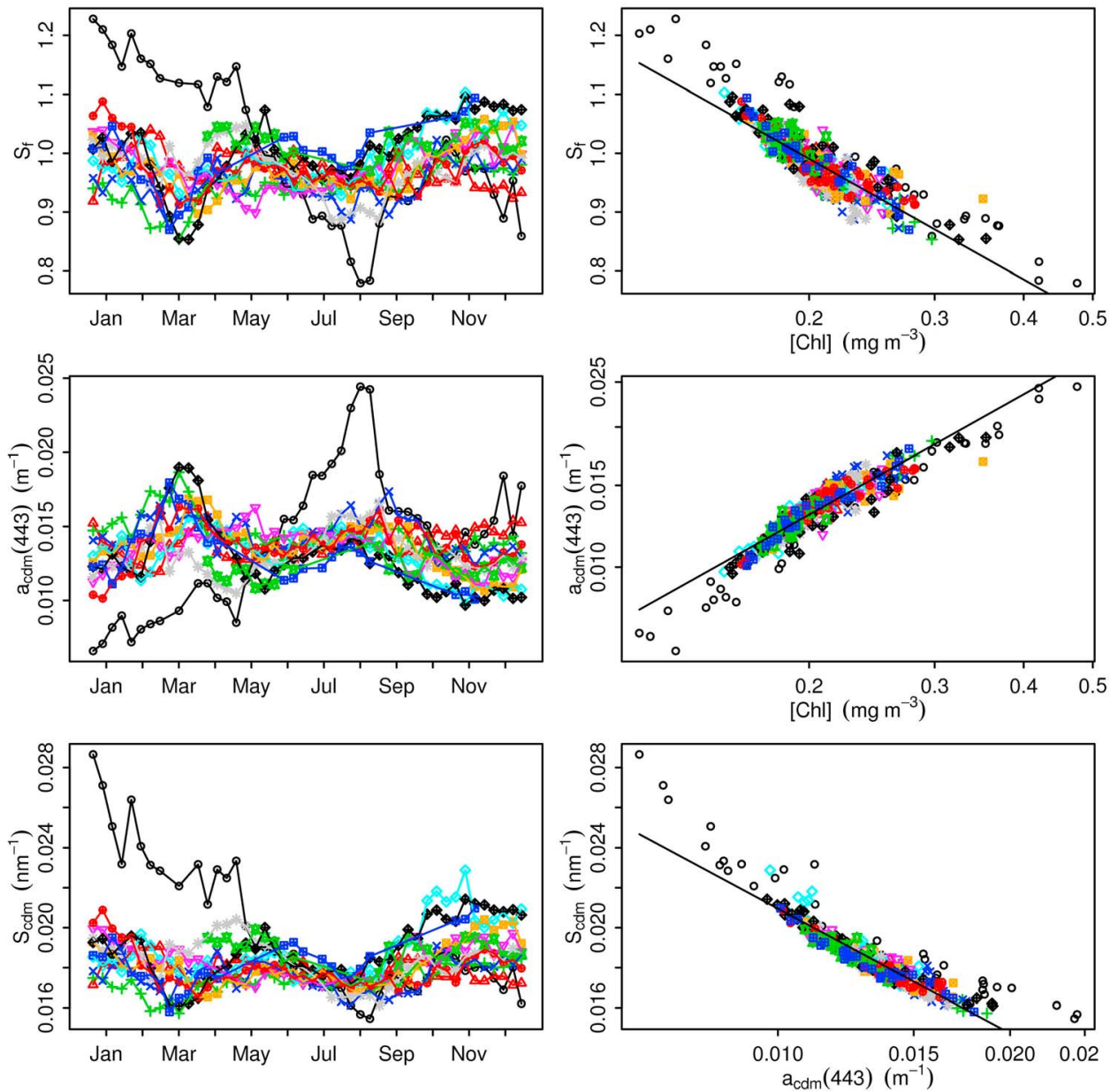

Figure 6. Time series of the various parameters, derived from 8-day SeaWiFS composites and averaged over the Equatorial Pacific $\left(5^{\circ} \mathrm{S}-5^{\circ} \mathrm{N}, 80^{\circ} \mathrm{W}-170^{\circ} \mathrm{W}\right)$, along the period from January 1998 to December 2009. (left, top to bottom) Chlorophyll $a$ concentration [Chl] (in $\mathrm{mg}^{-3}$ ), size factor of phytoplankton $\mathrm{S}_{\mathrm{f}}$ (dimensionless), absorption coefficient of CDM at $443 \mathrm{~nm}\left(\right.$ in $\left.^{-1}\right)$, spectral slope of CDM absorption, $\mathrm{S}_{\mathrm{cdm}}\left(\right.$ in $\mathrm{nm}^{-1}$ ). (right, top to bottom) Variations of $\mathrm{S}_{\mathrm{f}}$ versus [Chl], $\mathrm{a}_{\mathrm{cdm}}(443)$ versus [Chl], and $\mathrm{S}_{\mathrm{cdm}}$ versus $\mathrm{a}_{\mathrm{cdm}}(443)$. The regression lines are displayed as continuous lines. Note that the scales are logarithmic for $\mathrm{a}_{\mathrm{cdm}}(443)$ and [Chl], and linear for $\mathrm{S}_{\mathrm{f}}$ and $\mathrm{S}_{\mathrm{cdm}}$.

of picophytoplankton. During the mature phase of El Niño (January to April 1998), [Chl] is particularly low, with values between 0.10 and $0.15 \mathrm{mg} \mathrm{m}^{-3}$, i.e., about half the concentration observed during the same months in other years. In addition, $\mathrm{S}_{\mathrm{f}}$ is distinctively higher (between 1 and 1.2), indicating an increased proportion of smaller and less pigment packaged cells. Conversely, during La Niña, [Chl] values rapidly increase toward a strong maximum (around $0.5 \mathrm{mg} \mathrm{m}^{-3}$ in July-August 1998). The spatial extent of the
1998 bloom was recognized as the largest ever observed for the Equatorial Pacific, with a high abundance of diatoms [Chavez et al., 1999]. Accordingly, the $\mathrm{S}_{\mathrm{f}}$ values drop down to less than 0.8 in August 1998. The presence of large diatoms has been detected during this period with the PHYSAT method [Alvain et al., 2008, Figure 12] (note that the maximum in [Chl] they evidenced by averaging over the 1998-2006 period is, actually, exclusively due to the 1998 La Niña bloom). 
[25] For all 12 years analyzed here, the $\mathrm{S}_{\mathrm{f}}$ values were inversely correlated to algal biomass, with $75 \%$ of the $S_{f}$ variations explained by the [Chl] variations (Figure 6, top right). Note, however, that the $S_{\mathrm{f}}$ values for the mature phase of El Niño (January to April 1998) and for the La Niña period (June to September 1998) depart from the average relationship.

[26] The seasonal and interannual variations of $\mathrm{CDM}$ absorption coefficients, $\mathrm{a}_{\mathrm{cdm}}(443)$, also closely follow those of [Chl], and $85 \%$ of these variations are explained by those of [Chl] (Figure 6, middle right). The strong algal bloom in August 1998 is accompanied by an exceptionally intense CDM maximum. During the mature El Niño / La Niña period, however, $\mathrm{a}_{\mathrm{cdm}}(443)$ values slightly depart from the average log-log relationship. Note that some CDM maxima, such as those occurring in March 2004 and March 2006, appear to last longer than the corresponding Chl maxima. This can be interpreted as additional evidence that CDOM, as a product of phytoplankton degradation, frequently subsists at a high level during the late phase of an algal bloom [see, e.g., Hu et al., 2006].

[27] The slope of CDM absorption, $\mathrm{S}_{\mathrm{cdm}}$, reveals a weakly marked seasonal cycle and a weak interannual variability, except for the year 1998 where $S_{\text {cdm }}$ values are exceptionally high during the mature phase of El Niño, and reveal a minimum (corresponding to the $\mathrm{a}_{\mathrm{cdm}}(443)$ maximum) in August (Figure 6, bottom). The $\mathrm{S}_{\mathrm{cdm}}$ values show an overall trend to decrease with increasing $a_{c d m}(443)$. The $S_{c d m}$ values for the year 1998, however, depart from the average relationship, both during the oligotrophic period (mature phase of El Niño, January-April 1998), and during the La Niña phase (MaySeptember 1998) with $S_{c d m}$ values which are larger than expected. As the high $\mathrm{a}_{\mathrm{cdm}}$ values during this period do not suggest strong photobleaching, the high $\mathrm{S}_{\mathrm{cdm}}$ values (comparatively to the CDM content) might indicate the presence of newly produced CDOM [Nelson et al., 2004].

\subsubsection{North Atlantic $\left(40^{\circ} \mathrm{N}-70^{\circ} \mathrm{N}, 10^{\circ} \mathrm{W}-60^{\circ} \mathrm{W}\right)$}

[28] In this oceanic region, the most prominent feature in the [Chl] seasonal cycle is the large spring bloom from April to June, followed by a slow and continuous decrease until December. Consistently, the $\mathrm{S}_{\mathrm{f}}$ values drop down from $0.6-0.8$ in winter to $0.35-0.5$ during the bloom (Figure 7, top). Alvain et al. [2008] stated that phytoplankton there is dominated year-round by nanoeukaryotes, but with a larger contribution by diatoms during the spring bloom. On the other hand, they also observed a one-month shift between the [Chl] maximum (in May) and the maximum occurrence of diatoms (in June), while no such shift is observed for $\mathrm{S}_{\mathrm{f}}$. In this area, $73 \%$ of the $S_{f}$ variations are accounted for by [Chl] variations (Figure 7), and statistical tests demonstrate that the average $S_{\mathrm{f}}$ versus [Chl] relationship differs significantly from that observed for the Equatorial Pacific $(\mathrm{p}<$ 0.001; Figure 9a).

[29] The spring bloom is accompanied by a large maximum in CDM absorption and the evolutions appear to be parallel (Figure 7, middle). Note, however, that some CDM peaks (e.g., those appearing in April 1999 or 2001) are much more intense than the corresponding $\mathrm{Chl}$ peaks. The $\mathrm{a}_{\mathrm{cdm}}$ (443) versus [Chl] relationship is tight (determination coefficient 0.93 ), and is significantly different from that observed for the Equatorial Pacific $(p<0.0001$; Figure $9 b)$.
[30] The $S_{c d m}$ values show a strong seasonal cycle, with a large depression (and a minimum around $0.012 \mathrm{~nm}^{-1}$ ) corresponding to the spring maximum in $\mathrm{a}_{\mathrm{cdm}}(443)$, and a summer maximum around 0.016-0.018 $\mathrm{nm}^{-1}$ (Figure 7, bottom). These relatively high values during summer (associated with low values for $\left.\mathrm{a}_{\mathrm{cdm}}(443)\right)$ likely result from the photobleaching of CDOM, which induces a shift from large molecular weight complexes (absorbing at longer wavelengths) to smaller complexes (absorbing at shorter wavelengths) [e.g., Whitehead et al., 2000]. Contrary to the Equatorial Pacific, in this region there is no single relationship between $\mathrm{S}_{\mathrm{cdm}}$ and $\mathrm{a}_{\mathrm{cdm}}$ (443), but two distinct relationships, corresponding to the summer period (June to September, with high $\mathrm{S}_{\mathrm{cdm}}$ values) and to the rest of the year. This suggests that photobleaching may affect not only the amplitudes of $\mathrm{S}_{\mathrm{cdm}}$ and $\mathrm{a}_{\mathrm{cdm}}$, but also the average relationship between them. 3.2.3. Mediterranean Sea $\left(29^{\circ} \mathrm{N}-49^{\circ} \mathrm{N}, 0.5^{\circ} \mathrm{E}-29.5^{\circ} \mathrm{E}\right)$

[31] As already evidenced by earlier studies [e.g., Bosc et al., 2004; Barale et al., 2008], the seasonal cycle of [Chl] in the Mediterranean Sea is characterized by a large maximum in winter and spring, a minimum in summer, and also by a rather large interannual variability during the period of the SeaWiFS time series (Figure 8, top). Accordingly, the $\mathrm{S}_{\mathrm{f}}$ values increase from about $0.6-0.7$ in winter, toward 1 or more in summer, which suggests a decrease in cell size from winter-spring to summer. As observed in other regions, $\mathrm{S}_{\mathrm{f}}$ is inversely correlated with [Chl], with however a large scatter (determination coefficient 0.80 ). The $\mathrm{S}_{\mathrm{f}}$ versus [Chl] relationship is significantly different from those observed in the two other areas $(p<0.0001$; Figure $9 a)$.

[32] The seasonal cycle of CDM absorption follows rather closely the cycle of algal biomass (Figure 8, middle). This direct correlation is favored by photobleaching of CDOM in summer, which is also the most oligotrophic period. This results in a general correlation between $\mathrm{a}_{\mathrm{cdm}}(443)$ and [Chl] (determination coefficient 0.85 ), with a relationship which differs significantly from that observed for the Equatorial Pacific ( $\mathrm{p}<0.0001$; Figure 9b).

[33] The $S_{c d m}$ values also reveal a strongly marked seasonal cycle, rather reproducible from year to year (Figure 8, bottom). As in the North Atlantic, the high $\mathrm{S}_{\mathrm{cdm}}$ values in summer likely result from the photobleaching of CDOM. The range of variation spanned by $S_{\mathrm{cdm}}(0.015$ to 0.030 $\mathrm{nm}^{-1}$ ) is the largest observed for the three regions (note that the range experienced by $a_{c d m}(443)$ is comparable for these three regions, with a three- to fourfold variation along the year). The increase in $\mathrm{S}_{\mathrm{cdm}}$ due to bleaching is here $>50 \%$, whereas Moran et al. [2000] observed only a 6 to $10 \%$ increase for a $60 \%$ bleached CDOM in estuarine waters. The average $S_{c d m}$ versus $a_{c d m}$ (443) relationship is rather tight (89\% of the variations in $\mathrm{S}_{\mathrm{cdm}}$ explained by those of $a_{\text {cdm }}(443)$ ), and significantly different from those observed for the other regions $(\mathrm{p}<0.0001$; Figure $9 \mathrm{c})$. For a given CDM content, slopes of CDM absorption are on average higher in Mediterranean waters than in the other regions, which may indicate variations in the composition of CDOM pools, or the presence of smaller molecular weight CDOM complexes produced by photobleaching [e.g., Nelson et al., 2004]. As the contribution of CDOM to CDM is generally much larger than that of non-algal particles [Siegel et al., 

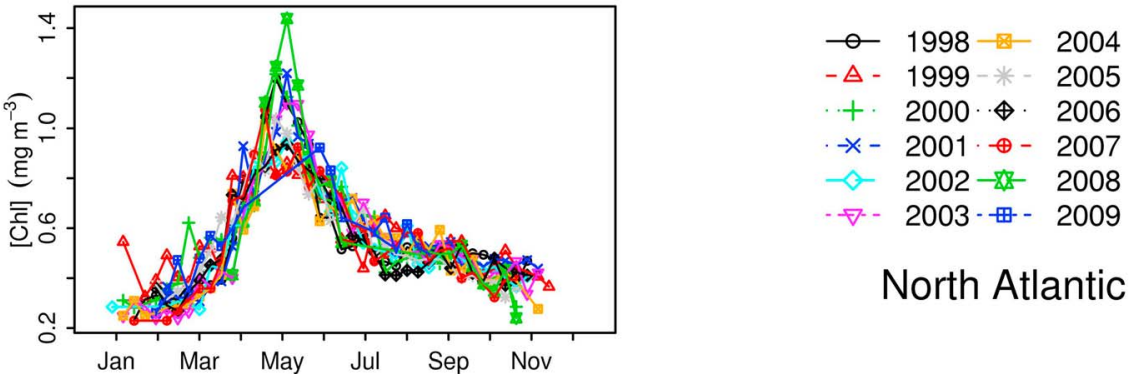

North Atlantic
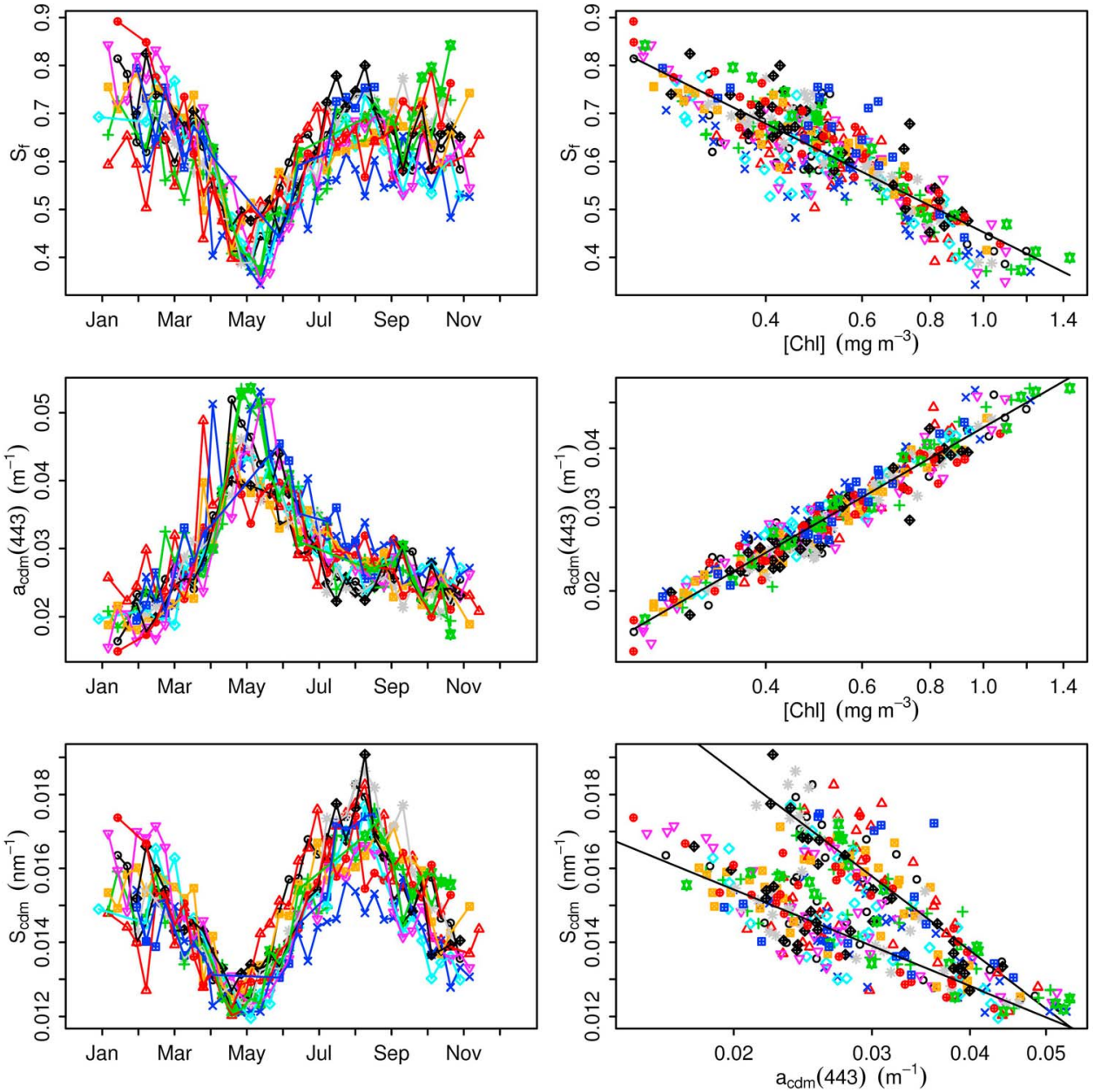

Figure 7. Same as Figure 6, for the North Atlantic $\left(40^{\circ} \mathrm{N}-70^{\circ} \mathrm{N}, 10^{\circ} \mathrm{W}-60^{\circ} \mathrm{W}\right)$. (bottom) For the $\mathrm{S}_{\mathrm{cdm}}$ versus $\mathrm{a}_{\mathrm{cdm}}(443)$ relationship, the two regression lines correspond to the summer period (June to September, upper line) and to the rest of the year (lower line).

2002], the possible variations in the CDOM to CDM ratio are expected to have a weak impact on the $\mathrm{S}_{\mathrm{cdm}}$ variations.

\section{Summary and Conclusions}

[34] Application of the Ciotti and Bricaud [2006] method to the SeaWiFS L3 global data set provided us with parameters that could be interpreted to describe spatial and temporal variations in the average size of dominant groups of phytoplankton communities $\left(\mathrm{S}_{\mathrm{f}}\right)$, and in the amplitude $\left(\mathrm{a}_{\mathrm{cdm}}(443)\right)$ and spectral shape $\left(\mathrm{S}_{\mathrm{cdm}}\right)$ of CDM absorption, as compared to those of surface chlorophyll concentration. At regional scales, our goal was to show that the retrieved parameters may vary according to various trends among distinct areas. Note, however, that the derived relationships are not designed for use in predictive applications or models.

[35] As expected, at the global scale, $[\mathrm{Chl}]$ and $\mathrm{S}_{\mathrm{f}}$ were correlated, with however a large scatter. At the scale of large oceanic areas, $\mathrm{S}_{\mathrm{f}}$ revealed large seasonal and interannual variations, generally inverse to those of [Chl], and the average $S_{f}$ versus [Chl] relationships appeared to be variable with the considered area. This is consistent with in situ 

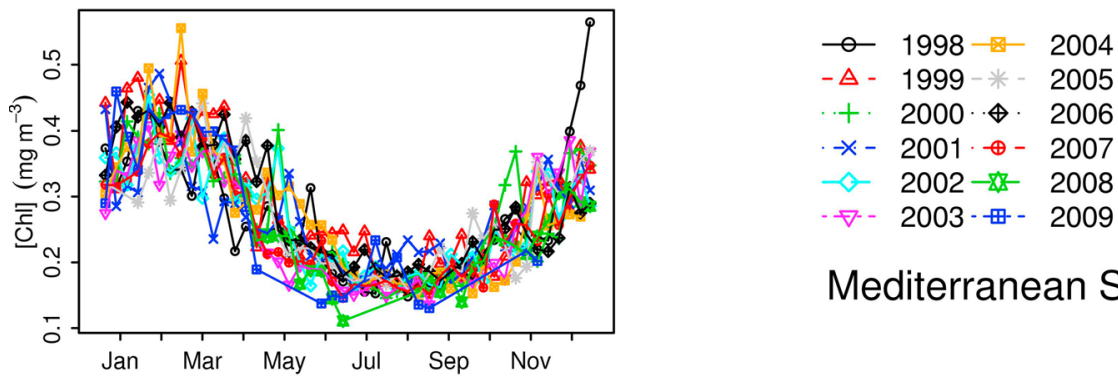

\section{Mediterranean Sea}
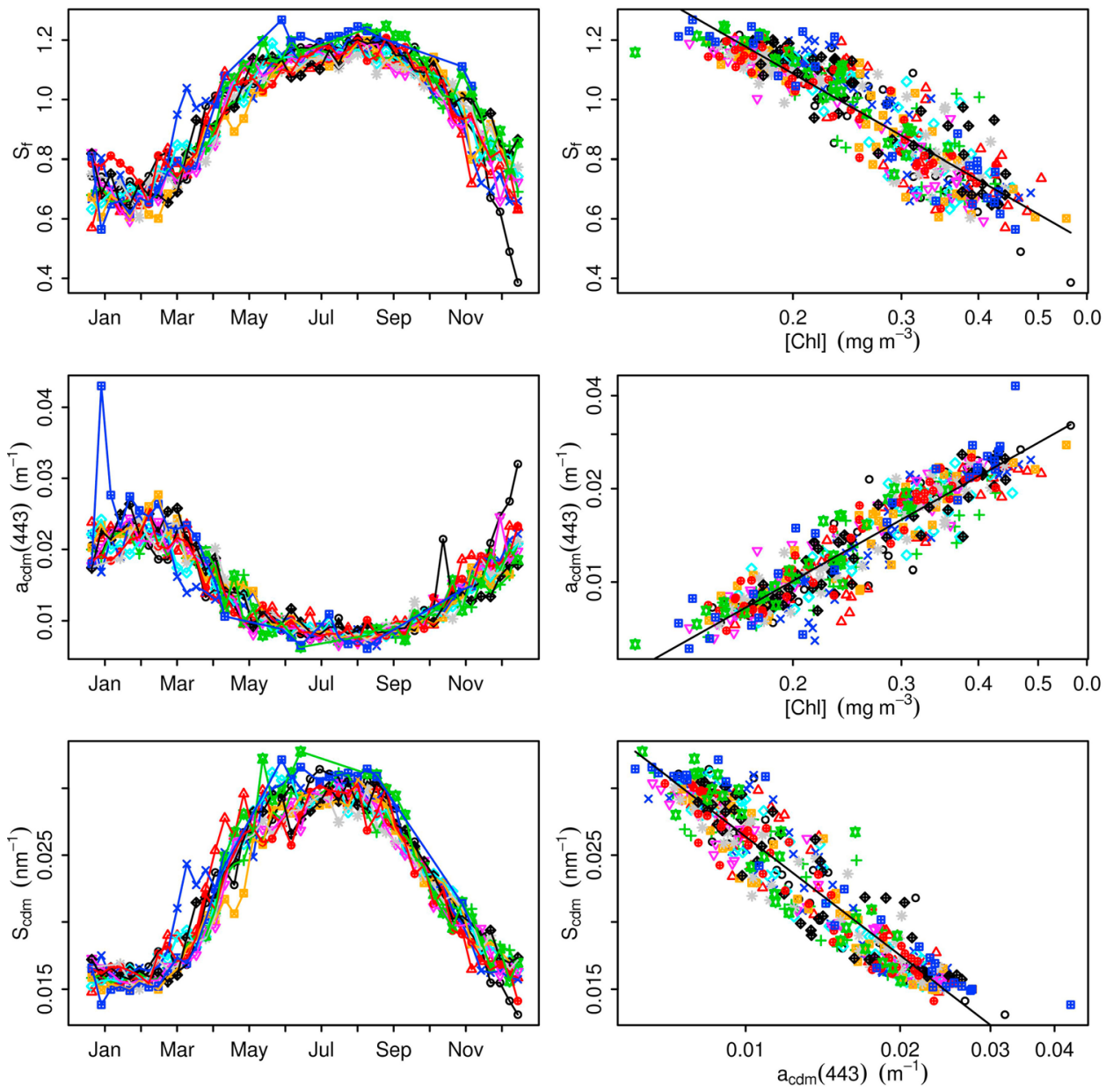

Figure 8. Same as Figure 6, for the Mediterranean Sea $\left(29^{\circ} \mathrm{N}-49^{\circ} \mathrm{N}, 0.5^{\circ} \mathrm{E}-29.5^{\circ} \mathrm{E}\right)$.

studies suggesting that, for a given [Chl], the dominant size of populations varies from one oceanic area to the other [e.g., Bricaud et al., 2004]. It is again pointed out that the retrieval of the algal size factor is based on the shape of the normalized algal absorption spectrum, independently from chlorophyll concentration. This emphasizes the advantage of methods in which the retrieval of algal size is not linked to [Chl]. It must be kept in mind, however, that various sources of error are inherent to the various methods [see Nair et al., 2008; Brewin et al., 2011]. In our method, for instance, dominant cell size is retrieved from variations in spectral shape of absorption that may occur independently from algal size variations themselves (e.g., because of variations in light conditions or nutrient availability), thus inducing errors in $\mathrm{S}_{\mathrm{f}}$ estimates. Still more importantly, the retrieval of $S_{f}$ remains tricky in very clear waters, where the total absorption coefficients are close to those of pure seawater.

[36] The retrieved absorption coefficients of colored detrital matter at $443 \mathrm{~nm}, \mathrm{a}_{\mathrm{cdm}}(443)$, also presented large seasonal and interannual variations, generally correlated to those of $[\mathrm{Chl}]$. The average $\mathrm{a}_{\mathrm{cdm}}$ versus [Chl] relationships were found to be relatively stable from one area to the other. CDM maxima thus occurred simultaneously to algal blooms, but in some occasions appeared to last longer, possibly as a result of local production of CDOM during the late phase of the blooms.

[37] One original product of our method is the spectral slope of CDM absorption, $\mathrm{S}_{\mathrm{cdm}}$. At the global scale, $\mathrm{S}_{\mathrm{cdm}}$ experienced ranges of variation larger than expected 

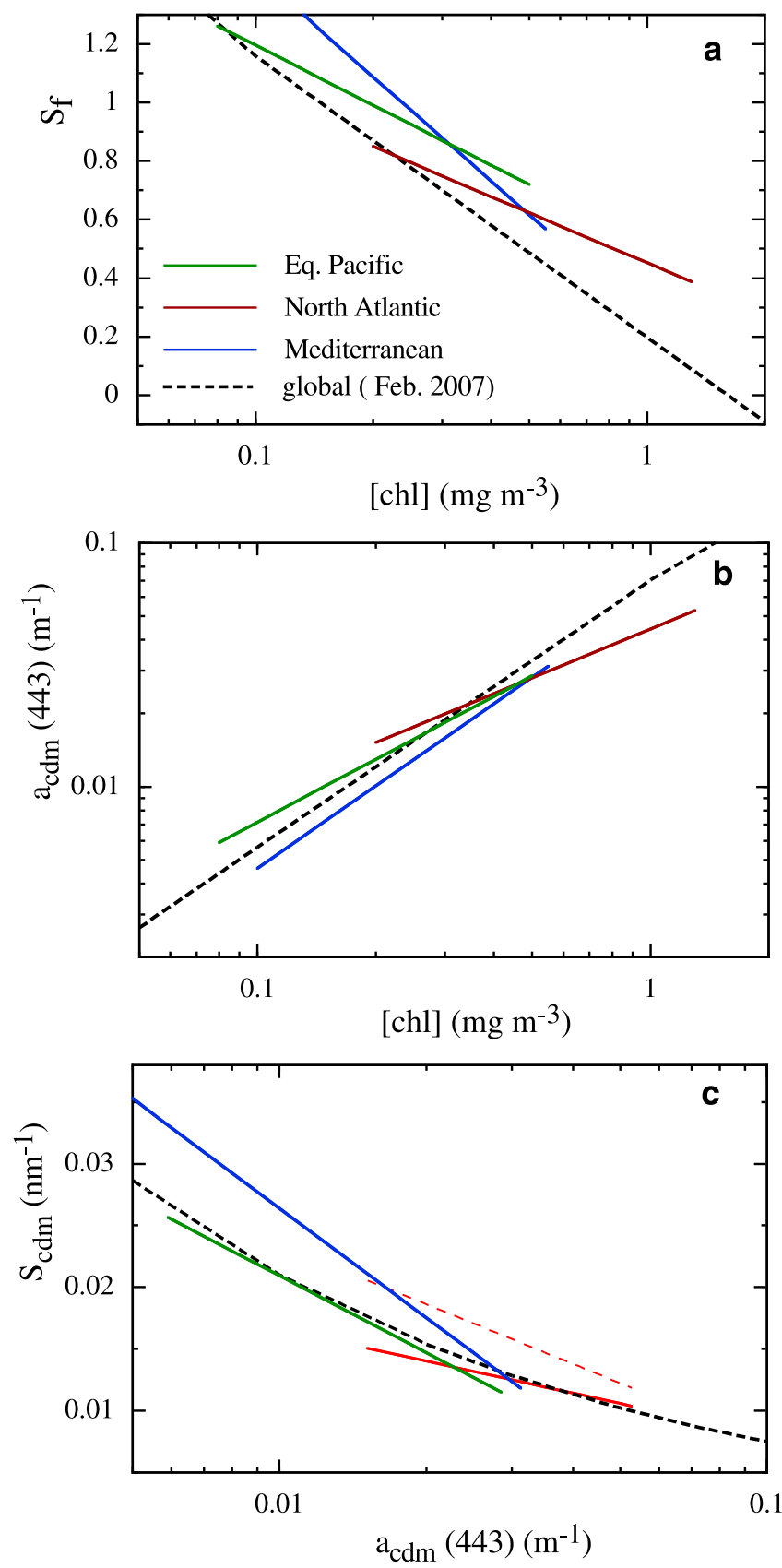

Figure 9. Relationships obtained by regression analyses for the three oceanic areas (as shown in Figures 6-8, right), between (a) $\mathrm{S}_{\mathrm{f}}$ and [Chl], (b) $\mathrm{a}_{\mathrm{cdm}}(443)$ and [Chl], and (c) $\mathrm{S}_{\mathrm{cdm}}$ and $\mathrm{a}_{\mathrm{cdm}}(443)$. In Figure $9 \mathrm{c}$, the dashed and continuous lines for the North Atlantic represent the relationships observed for summer and for the rest of the year, respectively. The global relationships obtained for the monthly image of February 2007 (Figures 2, 4 and 5) are shown for comparison.

(approximately from 0.010 to $0.035 \mathrm{~nm}^{-1}$, when excluding the clearest waters), and varied roughly inversely to the magnitude of CDM absorption. At a more regional scale, the average $S_{c d m}$ versus $a_{c d m}$ relationships varied from one oceanic area to the other. Strong seasonal cycles were observed for $\mathrm{S}_{\mathrm{cdm}}$ over the considered oceanic regions, and were largely reproducible from year to year. A notable exception was the Equatorial Pacific during the 1998 El Niño event, where remarkably high $\mathrm{S}_{\mathrm{cdm}}$ values appeared, and during La Niña period, where values deviated from the average $S_{c d m}$ versus $a_{c d m}$ relationship, possibly indicating the presence of newly produced CDOM. The largest seasonal variations (and the highest $\mathrm{S}_{\mathrm{cdm}}$ values) were observed in the Mediterranean, where they were clearly driven by photobleaching processes occurring in summer. Such variability questions the assumption, commonly used in bio-optical models, that $\mathrm{S}_{\mathrm{cdm}}$ can be considered as stable over space and time.

\section{Appendix A: Impact of Uncertainties Affecting Satellite-Retrieved Chlorophyll Concentrations Upon the Retrieval of CDM Absorption Coefficients}

[38] In our procedure, the chlorophyll concentration, as derived from SeaWiFS reflectances using the OC4v5 algorithm, is used as an input parameter to rescale the algal absorption spectrum at $505 \mathrm{~nm}$ [CB2006, equation 10], once its spectral shape has been fixed by the size factor $S_{f}$. The underlying assumption in the OC4v5 algorithm, however, is that there exists a general covariation between CDM content

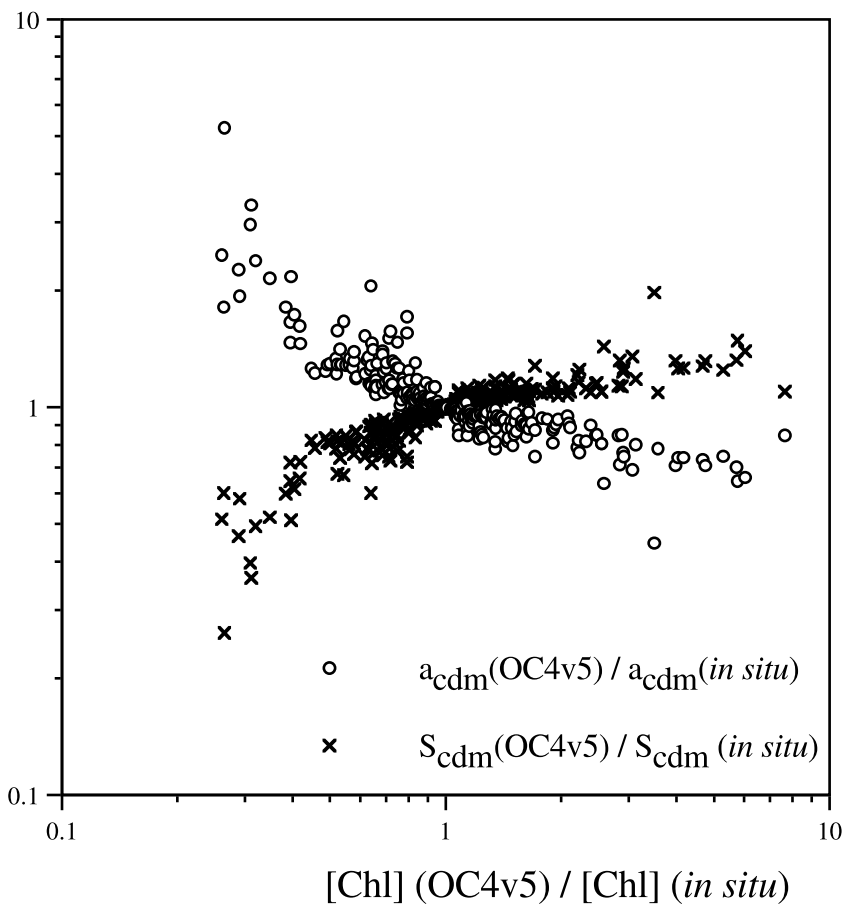

Figure A1. Ratios of CDM absorption coefficients at $443 \mathrm{~nm}\left(\mathrm{a}_{\mathrm{cdm}}(443)\right)$ and of spectral slopes $\left(\mathrm{S}_{\mathrm{cdm}}\right)$, retrieved using two [Chl] values as input data: (1) the value provided by the OC4v 5 algorithm, and (2) the in situ value, as a function of the ratio of these values. The data set used for these computations is the IOCCG in situ data set [Lee, 2006]. Note that for most stations where the OC4v5-to-in situ chlorophyll ratio present extreme values, the application of the procedure leads to invalid retrievals (no convergence in the optimization). 
and algal biomass [Siegel et al., 2005]. Therefore, the chlorophyll concentration provided by the OC4v5 algorithm may be largely in error, especially in coastal areas, or in oceanic areas with "anomalous" CDM contents. With a view to estimating how this possible error on chlorophyll concentration may affect the retrieval of CDM absorption coefficients, we have applied our procedure to the IOCCG in situ data set, which is a subset of the NOMAD database including 656 stations both in Case 1 and Case 2 waters [Lee, 2006].

[39] Using the field measurements of remote sensing reflectances, the OC4 v5 algorithm can be applied to derive the "retrieved chlorophyll concentration." We can thus compare the absorption coefficient of CDM at $443 \mathrm{~nm}$, retrieved using either the in situ chlorophyll concentration or the retrieved chlorophyll concentration (Figure A1). It can be observed that (i) as expected, an overestimate (underestimate) in chlorophyll concentration leads to an underestimate (overestimate) in the CDM absorption coefficient; (ii) whereas the OC4v5-to-in situ chlorophyll ratio varies in the range $0.2-8$, the associated $\mathrm{a}_{\mathrm{cdm}}$ ratio varies in a much more restricted range, with most points in the range 0.7-3. The same observation stands for the $\mathrm{S}_{\mathrm{cdm}}$ ratio (with most points in the range $0.3-1.5$ ).

[40] This suggests that possible errors affecting the chlorophyll concentration have a limited impact on CDM retrievals. Therefore, such errors should not prevent "anomalous" CDM contents to be detected, even if in these areas CDM absorption coefficients are affected by larger errors than in areas where the chlorophyll concentration is correctly retrieved. Note also that in this in situ data set, Case 2 waters are largely represented, which contributes to the large variation range of the OC4v5-to-in situ chlorophyll ratio. When applying our procedure to global or regional satellite maps, the occurrence of such errors is expected to be much more limited, at least for oceanic Case 1 waters.

[41] Acknowledgments. The authors thank the NASA SeaWiFS project for providing the SeaWiFS global data set. They are very grateful to Hubert Loisel and David Desailly for providing their routines for the retrieval of total absorption coefficients, to Atsushi Matsuoka for help with statistical analyses, and to Heidi Sosik and an anonymous reviewer for their thorough and constructive comments. This study is a contribution to the GLOBPHY project (ANR-06-BLAN-0240), which was funded by Agence Nationale de la Recherche.

\section{References}

Aiken, J., J. R. Fishwick, S. J. Lavender, R. Barlow, G. F. Moore, H. Sessions, S. Bernard, J. Ras, and N. J. Hardman-Mountford (2007) Validation of MERIS reflectance and chlorophyll during the BENCAL cruise, October 2002: Preliminary validation and new products for phytoplankton types and photosynthetic parameters, Int. J. Remote Sens., 28, 497-516, doi:10.1080/01431160600821036.

Alvain, S., C. Moulin, Y. Dandonneau, and F. M. Bréon (2005), Remote sensing of phytoplankton groups in case 1 waters from global SeaWiFS imagery, Deep Sea Res., Part I, 52, 1989-2004, doi:10.1016/j. dsr.2005.06.015

Alvain, S., C. Moulin, Y. Dandonneau, and H. Loisel (2008), Seasonal distribution and succession of dominant phytoplankton groups in the global ocean: A satellite view, Global Biogeochem. Cycles, 22, GB3001, doi:10.1029/2007GB003154.

Anderson, T. R. (2005), Plankton functional type modelling: Running before we can walk?, J. Plankton Res., 27(11), 1073-1081.

Aumont, O., E. Meier-Reimer, S. Blain, and P. Monfray (2003), An ecosystem model of the global ocean including $\mathrm{Fe}, \mathrm{Si}, \mathrm{P}$ colimitations, Global Biogeochem. Cycles, 17(2), 1060, doi:10.1029/2001GB001745.

Babin, M., D. Stramski, G. M. Ferrari, H. Claustre, A. Bricaud, G. Obolensky, and N. Hoepffner (2003), Variations in the light absorption coefficients of phytoplankton, nonalgal particles, and dissolved organic matter in coastal waters around Europe, J. Geophys. Res., 108(C7), 3211, doi:10.1029/2001JC000882.

Barale, V., J. M. Jacquet, and M. Ndiaye (2008), Algal blooming patterns and anomalies in the Mediterranean Sea as derived from the SeaWiFS data set (1998-2003), Remote Sens. Environ., 112, 3300-3313, doi:10.1016/j.rse. 2007.10.014.

Bélanger, S., M. Babin, and P. Larouche (2008), An empirical ocean color algorithm for estimating the contribution of chromophoric dissolved organic matter to total light absorption in optically complex waters, J. Geophys. Res., 113, C04027, doi:10.1029/2007JC004436.

Blough, N. V., and R. Del Vecchio (2002), Chromophoric DOM in the coastal environment, in Biogeochemistry of Marine Dissolved Organic Matter, edited by D. Hansell and C. Carlson, pp. 509-546, Academic, San Diego, Calif.

Bosc, E., A. Bricaud, and D. Antoine (2004), Seasonal and interannual variability in algal biomass and primary production in the Mediterranean Sea, as derived from four years of SeaWiFS observations, Global Biogeochem. Cycles, 18, GB1005, doi:10.1029/2003GB002034.

Brewin, R. J. W., et al. (2011), An intercomparison of bio-optical techniques for detecting dominant phytoplankton size class from satellite remote sensing, Remote Sens. Environ., 115, 325-339, doi:10.1016/j. rse.2010.09.004.

Bricaud, A., A. Morel, M. Babin, K. Allali, and H. Claustre (1998), Variations of light absorption by suspended particles with chlorophyll $a$ concentration in oceanic (case 1) waters: Analysis and implications for bio-optical models, J. Geophys. Res., 103, 31,033-31,044, doi:10.1029/ 98JC02712.

Bricaud, A., E. Bosc, and D. Antoine (2002), Algal biomass and sea surface temperature in the Mediterranean Basin: Intercomparison of data from various satellite sensors, and implications for primary production estimates, Remote Sens. Environ., 81, 163-178, doi:10.1016/S00344257(01)00335-2.

Bricaud, A., H. Claustre, J. Ras, and K. Oubelkheir (2004), Natural variability of phytoplanktonic absorption in oceanic waters: Influence of the size structure of algal populations, J. Geophys. Res., 109, C11010, doi:10.1029/ 2004JC002419.

Bricaud, A., A. M. Ciotti, A. Silio-Calzada, and B. Gentili (2006), Retrievals of a size parameter for phytoplankton and light absorption by colored detrital matter from ocean color measurements: validation and application to SeaWiFS images, paper presented at Ocean Optics XVIII, The Oceanogr. Soc., NASA, CNES, Montreal, Que., Canada, 9-13 Oct.

Bricaud, A., M. Babin, H. Claustre, J. Ras, and F. Tièche (2010), Light absorption properties and absorption budget of Southeast Pacific waters, J. Geophys. Res., 115, C08009, doi:10.1029/2009JC005517.

Brown, C. A., Y. Huot, P. J. Werdell, B. Gentili, and H. Claustre (2008), The origin and global distribution of second order variability in satellite ocean color and its potential applications to algorithm development, Remote Sens. Environ., 112, 4186-4203, doi:10.1016/j.rse.2008.06.008.

Byrd, R. H., P. Lu, J. Nocedal, and C. Zhu (1995), A limited memory algorithm for bound constrained optimization, SIAM J. Sci. Comput., 16, 1190-1208, doi:10.1137/0916069.

Campbell, J. W., J. M. Blaisdell, and M. Darzi (1995), Level-3 SeaWiFS data products: Spatial and temporal binning algorithms, NASA Tech. Memo., TM-104566, vol. 32, 73 pp.

Carder, K. L., R. G. Steward, G. R. Harvey, and P. B. Ortner (1989), Marine humic and fulvic acids: Their effects on remote sensing of ocean chlorophyll, Limnol. Oceanogr., 34, 68-81, doi:10.4319/lo.1989.34.1.0068.

Carder, K. L., F. R. Chen, Z. P. Lee, S. K. Hawes, and D. Kamykowski (1999), Semianalytic Moderate-Resolution Imaging Spectrometer algorithms for chlorophyll $a$ and absorption with bio-optical domains based on nitrate-depletion temperatures, J. Geophys. Res., 104, 5403-5421, doi:10.1029/1998JC900082.

Chavez, F. P., K. R. Buck, and R. T. Barber (1990), Phytoplankton taxa in relation to primary production in the Equatorial Pacific, Deep Sea Res., Part A, 37(11), 1733-1752, doi:10.1016/0198-0149(90)90074-6.

Chavez, F., P. G. Strutton, G. E. Friederich, R. A. Feely, G. C. Feldman, D. G. Foley, and M. J. McPhaden (1999), Biological and chemical response of the Equatorial Pacific Ocean to the 1997-98 El Niño, Science, 286, 2126-2131, doi:10.1126/science.286.5447.2126.

Chen, R. F., and J. L. Bada (1992), The fluorescence of dissolved organic matter in seawater, Mar. Chem., 37, 191-221, doi:10.1016/0304-4203(92) 90078-O.

Ciotti, A. M., and A. Bricaud (2006), Retrievals of a size parameter for phytoplankton and light absorption by colored detrital matter from water-leaving radiances at SeaWiFS channels in a continental shelf region off Brazil, Limnol. Oceanogr. Methods, 4, 237-253, doi:10.4319/ lom.2006.4.237

Ciotti, A. M., M. R. Lewis, and J. J. Cullen (2002), Assessment of the relationships between dominant cell size in natural phytoplankton 
communities and the spectral shape of the absorption coefficient, Limnol. Oceanogr., 47, 404-417, doi:10.4319/lo.2002.47.2.0404

Coble, P. (2007), Marine optical biogeochemistry: The chemistry of ocean color, Chem. Rev., 107, 402-418, doi:10.1021/cr050350+.

D'Sa, E., and R. L. Miller (2003), Bio-optical properties in waters influenced by the Mississippi River during low flow conditions, Remote Sens. Environ., 84(4), 538-549, doi:10.1016/S0034-4257(02)00163-3.

Devred, E., S. Sathyendranath, V. Stuart, H. Maass, O. Ulloa, and T. Platt (2006), A two-component model of phytoplankton absorption in the open ocean: Theory and applications, J. Geophys. Res., 111, C03011, doi: $10.1029 / 2005 \mathrm{JC} 002880$.

Gege, P. (1998), Characterization of the phytoplankton in Lake Constance for classification by remote sensing, Arch. Hydrobiol., 53, 179-193.

Green, S. A., and N. V. Blough (1994), Optical absorption and fluorescence properties of chromophoric dissolved organic matter in natural waters, Limnol. Oceanogr., 39(8), 1903-1916, doi:10.4319/lo.1994.39.8.1903.

Hirata, T., J. Aiken, N. Hardman-Mountford, T. J. Smyth, and R. G. Barlow (2008), An absorption model to determine phytoplankton size classes from satellite ocean colour, Remote Sens. Environ., 112, 3153-3159, doi:10.1016/j.rse.2008.03.011.

Hu, C., Z. Lee, F. E. Muller-Karger, K. L. Carder, and J. J. Walsh (2006), Ocean color reveals phase shift between marine plants and yellow substance, IEEE Geosci. Remote Sens. Lett., 3(2), 262-266, doi:10.1109/ LGRS.2005.862527.

Johannessen, S. C., W. L. Miller, and J. J. Cullen (2003), Calculation of UV attenuation and colored dissolved organic matter absorption spectra from measurements of ocean color, J. Geophys. Res., 108(C9), 3301, doi:10.1029/2000JC000514.

Kahru, M., and B. G. Mitchell (2001), Seasonal and nonseasonal variability of satellite-derived chlorophyll and colored dissolved organic matter concentration in the California Current, J. Geophys. Res., 106, 2517-2529, doi:10.1029/1999JC000094.

Kitidis, V., A. P. Stubbins, G. Uher, R. C. Upstill Goddard, C. S. Law, and E. M. S. Woodward (2006), Variability of chromophoric organic matter in surface waters of the Atlantic Ocean, Deep Sea Res., Part II, 53, $1666-1684$

Kopelevich, O. V., and V. I. Burenkov (1977), Relation between the spectral values of the light absorption coefficients of sea water, phytoplanktonic pigments, and the yellow substance, Oceanology, Engl. Transl., 17, 278-282.

Kostadinov, T. S., D. A. Siegel, and S. Maritorena (2009), Retrieval of particle size distribution from satellite ocean color observations, J. Geophys. Res., 114, C09015, doi:10.1029/2009JC005303.

Landry, M. R., et al. (1997), Iron and grazing constraints on primary production in the central Equatorial Pacific: An EqPac synthesis, Limnol. Oceanogr., 42(3), 405-418, doi:10.4319/lo.1997.42.3.0405.

Le Quéré, C., et al. (2005), Ecosystem dynamics based on plankton functional types for global ocean biogeochemistry models, Global Change Biol., 11, 2016-2040.

Lee, Z. P. (Ed.) (2006), Remote sensing of inherent optical properties: Fundamentals, tests of algorithms, and applications, IOCCG Rep. 5, Int Ocean Colour Coord. Group, Dartmouth, N. S., Canada.

Lee, Z., K. L. Carder, and R. A. Arnone (2002), Deriving quasi-inherent optical properties from water color: A multiband quasi-analytical algorithm for optically deep waters, Appl. Opt., 41(27), 5755-5772, doi:10.1364/ AO.41.005755.

Loisel, H., and A. Poteau (2006), Inversion of IOP based on Rrs and remotely retrieved Kd, in Remote Sensing of Inherent Optical Properties. Fundamentals, Tests of Algorithms, and Applications, edited by Z. P. Lee, IOCCG Rep. 5, pp. 35-41, Int. Ocean Colour Coord. Group, Dartmouth, N. S., Canada.

Loisel, H., and D. Stramski (2000), Estimation of the inherent optical properties of natural waters from irradiance attenuation coefficient and reflectance in the presence of Raman scattering, Appl. Opt., 39, 3001-3011, doi:10.1364/AO.39.003001

Loisel, H., J.-M. Nicolas, A. Sciandra, D. Stramski, and A. Poteau (2006), Spectral dependency of optical backscattering by marine particles from satellite remote sensing of the global ocean, J. Geophys. Res., 111, C09024, doi:10.1029/2005JC003367.

Mannino, A., M. E. Russ, and S. B. Hooker (2008), Algorithm developmen and validation for satellite-derived distributions of DOC and CDOM in the U.S. Middle Atlantic Bight, J. Geophys. Res., 113, C07051, doi:10.1029/ 2007JC004493.

Maritorena, S., D. A. Siegel, and A. R. Peterson (2002), Optimization of a semi-analytical ocean color model for global-scale applications, Appl. Opt., 41, 2705-2714, doi:10.1364/AO.41.002705.

Mopper, K., and D. J. Kieber (2002), Photochemistry and cycling of carbon, sulfur, nitrogen and phosphorus, in Biogeochemistry of Marine
Dissolved Organic Matter, edited by D. A. Hansell and C. A. Carlson, pp. 455-507, Academic, San Diego, Calif., doi:10.1016/B978-0123238412/50011-7

Moran, M. A., W. M. Sheldon, and R. G. Zepp (2000), Carbon loss and optical property changes during long-term photochemical and biological degradation of estuarine dissolved organic matter, Limnol. Oceanogr., 45(6), 1254-1264, doi:10.4319/lo.2000.45.6.1254

Morel, A., and B. Gentili (2009), The dissolved yellow substance and the shades of blue in the Mediterranean Sea, Biogeosciences, 6, 2625-2636, doi:10.5194/bg-6-2625-2009.

Mouw, C. B., and J. A. Yoder (2010), Optical determination of phytoplankton size composition from global SeaWiFS imagery, J. Geophys. Res., 115, C12018, doi:10.1029/2010JC006337.

Nair, A., S. Sathyendranath, T. Platt, J. Morales, V. Stuart, M.-H. Forget, E. Devred, and H. Bouman (2008), Remote sensing of phytoplankton functional types, Remote Sens. Environ., 112, 3366-3375, doi:10.1016/j. rse.2008.01.021

Nelson, N. B., and D. A. Siegel (2002), Chromophoric DOM in the open ocean, in Biogeochemistry of Marine Dissolved Organic Matter, edited by D. A. Hansell and C. A. Carlson, pp. 547-578, Academic, San Diego, Calif., doi:10.1016/B978-012323841-2/50013-0.

Nelson, N. B., C. A. Carlson, and D. K. Steinberg (2004), Production of chromophoric dissolved organic matter by Sargasso Sea microbes, Mar. Chem., 89, 273-287, doi:10.1016/j.marchem.2004.02.017.

Nelson, N. B., D. A. Siegel, C. A. Carlson, C. Swan, W. M. Smethie Jr., and S. Khatiwala (2007), Hydrography of chromophoric dissolved organic matter in the North Atlantic, Deep Sea Res., Part I, 54, 710-731, doi:10.1016/j.dsr.2007.02.006.

Nelson, N. B., D. A. Siegel, C. A. Carlson, and C. M. Swan (2010), Tracing global biogeochemical cycles and meridional overturning circulation using chromophoric dissolved organic matter, Geophys. Res. Lett., 37 , L03610, doi:10.1029/2009GL042325.

Pope, R. M., and E. S. Fry (1997), Absorption spectrum (380-700 nm) of pure water. II. Integrating cavity measurements, Appl. Opt., 36, 8710-8722, doi:10.1364/AO.36.008710.

Raitsos, D. E., S. J. Lavender, C. D. Maravelias, J. Haralabous, A. J. Richardson, and P. C. Reid (2008), Identifying four phytoplankton functional types from space: An ecological approach, Limnol. Oceanogr., 53(2), 605-613, doi:10.4319/1o.2008.53.2.0605

Sieburth, J. M., V. Smetacek, and J. Lentz (1978), Pelagic ecosystem structure: Heterotrophic compartments of the plankton and their relationship to plankton size fractions, Limnol. Oceanogr., 23, 1256-1263, doi:10.4319/ 1o.1978.23.6.1256.

Siegel, D. A., S. Maritorena, N. B. Nelson, D. A. Hansell, and M. LorenziKayser (2002), Global distribution and dynamics of colored dissolved and detrital organic materials, J. Geophys. Res., 107(C12), 3228, doi:10.1029/2001JC000965.

Siegel, D. A., S. Maritorena, N. B. Nelson, M. J. Behrenfeld, and C. R. McClain (2005), Colored dissolved organic matter and its influence on the satellite-based characterization of the ocean biosphere, Geophys. Res. Lett., 32, L20605, doi:10.1029/2005GL024310.

Swan, C. M., D. A. Siegel, N. B. Nelson, C. A. Carlson, and E. Nasir (2009), Biogeochemical and hydrographic controls on chromophoric dissolved organic matter distribution in the Pacific Ocean, Deep Sea Res. Part I, 56, 2175-2192, doi:10.1016/j.dsr.2009.09.002.

Twardowski, M. S., E. Boss, J. M. Sullivan, and P. L. Donaghay (2004), Modeling the spectral shape of absorption by chromophoric dissolved organic matter, Mar. Chem., 89, 69-88, doi:10.1016/j.marchem.2004.02.008.

Uitz, J., H. Claustre, A. Morel, and S. Hooker (2006), Vertical distribution of phytoplankton communities in open ocean: An assessment based on surface chlorophyll, J. Geophys. Res., 111, C08005, doi:10.1029/ 2005JC003207.

Whitehead, R. F., S. de Mora, S. Demers, M. Gosselin, P. Monfort, and B. Mostajir (2000), Interactions of ultraviolet-B radiation, mixing, and biological activity on photobleaching of natural chromophoric dissolved organic matter: A mesocosm study, Limnol. Oceanogr., 45(2), 278-291, doi:10.4319/lo.2000.45.2.0278

Yentsch, C. S., and D. A. Phinney (1989), A bridge between ocean optics and microbial ecology, Limnol. Oceanogr., 34, 1694-1705, doi:10.4319/ lo.1989.34.8.1694.

A. Bricaud and B. Gentili, Laboratoire d'Océanographie de Villefranche, CNRS, Université Pierre et Marie Curie, BP 08, F-06238 Villefranchesur-Mer CEDEX, France. (annick@obs-vlfr.fr)

A. M. Ciotti, Laboratório Aquarela, Centro de Biologia Marinha, Universidade de São Paulo, Rod. Manoel Hipólito do Rego, Km 131,5, São Sebastião, SP cep 11600-000, Brazil. 